\title{
Sokağı Büyülemek: Gündelik Hayatın Seküler Temelleri Üzerine Bir Soruşturma
}

\author{
Sedat Doğan*
}

Öz: Sekülerleşme süreci, pek çok disipline uzunca bir dönem tartışacak malzeme üretmiştir. Ne var ki sosyal bilimlerin ölçek daraltması, özellikle de gündelik hayat çalışmalarına yönelmesi için moderniteye karşı kayda değer bir kuşkunun ortaya çıkmasını beklemek gerekmiştir. Bu kuşkunun olgunlaşmasıyla birlikte, 20. yüzyıl başlarında farklı amaç ve ön çıkarımlarla gündelik hayatı konu edinen çalışmalar, gündelik hayatın seküler bir kurgu olduğunu ima eden ortak sonuçlar üretmiştir. Makalenin amacı, bu imanın izini sürmek, gündelik hayatın seküler temellerini alternatif bir kavramsal çerçeve aracılığıyla soruşturmak ve gündelik hayatı dönüştürme fikrini tartışmaktır. Böyle bir tartışmanın temel uğrak noktaları, seküler ve dinsel ayrımı, sekülarizm tartışmaları, sekülerleşme ve rasyonelleşme teorileri ile gündelik hayat literatürü olmak durumundadır. Makalede bu kavram ve teorilere ilişkin alternatif bir okuma yapılacak ve bu bağlamda gündelik hayatı dönüştürme faaliyetine atfen stra-taktik uygulama kavramı önerilecektir. Makalenin odağını oluşturan gündelik hayatı dönüştürme fikri, gündelik hayatın mevcut dokusu, bu dokunun varlık ve süreklilik şartları, son olarak da gündelik hayatı dönüştürme açısından faillik ve niyet kavramına göndermede bulunur. Bu nedenle bir fail olarak İslamcılık da makalede tartışmaya açılacaktır.

Anahtar Kelimeler: Sekülarizm, Seküler, Dinsel, Sekülerleşme Teorisi, Rasyonalite, Büyü, Gündelik hayat, Stra-taktik Uygulama, İslamcılık.

\begin{abstract}
The process of secularization has produced many issues that will be discussed in a great number of disciplines for a long time to come. In order for social science's range of interest and influence to be narrowed, especially for its inclination toward works focusing on Everyday Life, it has been necessary to wait for significant doubt toward modernity to appear in society. Together with the ripening of this doubt, the different goals and pre-suppositions at the beginning of the 20th century, as well as works dealing with Everyday Life, mutual conclusions have been reached implying that Everyday Life is a secular construction. The goal of this article is three fold; the first is to follow the trail of belief, the second is to investigate Everyday Life's secular foundations through an alternative conceptual framework, and the third is to discuss Everyday Life's theory of transformation. The converging points of such a discussion lie in the separation of religion and state, discussions on secularism, secularization and rationalization theories, and the literature on Everyday Life. An alternative reading of the relations between these concepts and theories will be performed, and in doing so, the actions and implementations used for transformation by Everyday Life (the concept of sta-tactic implementation) will be presented. As will be the focus of this article, Everyday Life's theory of transformation includes the current pattern of Everyday Life, the conditions for the existence and survival of this pattern, and finally, the concept of intention and being an actor in daily life through Everyday Life's transformation perspective. For this reason, discussion will be opened up regarding Islamism's being an active agent in Everyday Life.
\end{abstract}

Keywords: Secularism, Secular, Religious, Rationality, Enchantment, Everyday Life, Sta-tactic Implementation, Islamism

* Arş. Gör., Erciyes Üniversitesi, Felsefe Bölümü.

Illetişim: sd_dogan@yahoo.com, Erciyes Üniversitesi, Felsefe Bölümü, Talas, Kayseri / Türkiye

Atıf@: Doğan, S. (2012). Sokağı büyülemek: gündelik hayatın seküler temelleri üzerine bir soruşturma. Insan \& Toplum, 2 (4), 83-117.

- DOl: http://dx.doi.org/10.12658/human.society.2.4.M0052 


\section{Giriş}

Modernite eleştirileri, oldukça geniş bir literatür ortaya çıkarmıştır. Bu eleştiriler aracıIığıyla, modernite üzerinden bir genelleme ile bütün üst anlatılara karşı bir şüphenin oluşup yaygınlaşmasına zemin hazırlandı. Gündelik hayat çalışmalarını makrosistemlerin/üst anlatıların zayıflamasına dayandıran Bovone (1989 aktaran Şahin ve Balta, 2001, s. 186), gündelik hayatın araştırılması konusunda üç temel eğilimden söz ediyor. Birincisi, gündelik hayata kapitalizm eleştirileri için bereketli bir alan olarak yaklaşan Marksizm'dir. İkincisi temellerini Husserl'de bulan, Berger ve Luckmann'ın temsil ettiği fenomenolojik yaklaşım, üçüncüsü ise Amerikan mikrososyolojik geleneğidir. Son yaklaşım, Mead ve Goffman'ın temsilciliği ile sembolik etkileşimcilik, Garfinkel'ın temsilciliği ile de etnometodolojik yaklaşım şeklinde iki farklı eğilim göstermiştir. Şahin ve Balta'ya (2001) göre, Marx ve Engels'te gündelik hayatın kurucu unsuru olan kimliğin maddi zemini vurgulanmakta, Gramsci ve Lukacs hegemonya ve şeyleşme kavramıyla aslında gündelik hayatta işçi sınıfının burjuvaziyle aynı kültürel örüntüler içinde bulunmasının devrimin olanaklıı̆̆ıyla ilişkisini tartışmakta, bunların araladığı kapıyı zorlayan Heller ve Lefebvre ise devrimin doğrudan gündelik hayatın dönüştürülmesi anlamına geldiğini vurgulamakta, özellikle Lefebvre gündelik hayatı modernlikle eş zamanlı olarak ele almaktadır. Metafizik uğraşıya sırtını dönerek öznenin dolaysız olarak ilişki kurabileceği fenomenlere yönelen ve çoğunlukla bir yöntem olarak algılanan fenomenoloji, bizatihi seküler bir dünyada çalışmakla birlikte Berger ve Luckmann (2008) gibi temsilcileri de gündelik hayatı 'şimdi' ve 'burada' gibi sekülerlikle özdeşleşmiş kavramlarla açıklanan, kurgulanmış bir gerçeklik olarak tasvir etmektedir. Mikrososyolojik yaklaşım ise kabaca insanların gündelik hayat pratikleri ile bunların konusu olan nesneleri nasıl anlamlandırdıkları üzerine yoğunlaşırken aslında eylemin rasyonel olarak açıklanabilecek olan yapısal niteliklere sahip olduğu ön kabulünden hareket eder. Tüm bu yaklaşımlar gündelik hayat tartışmaları için oldukça verimli çalışmalar ortaya koymuşsa da bu makalenin odağında duran gündelik hayatı dönüştürme fikri açısından tashihe ve yoruma muhtaç olduğunu belirtmek gerekir. Ancak makalenin sınırlılıkları nedeniyle Lefebvre ve De Certeau bağlamında bir tartışma yürüteceğiz.

-Günümüzde gündelik hayat çalışmalarını önemli kılan şey nedir?- sorusunun birçok yanıtı bulunmakla birlikte, literatürün ortaya çıkış nedeniyle çelişik gibi görünse de yanıtın, temelde üst anlatılardan duyulan şüphe paralelinde değil, aksine üst anlatılar ekseninde verilmesi gerektiği vurgulanmalıdır. Bu yanıt, yalnızca gündelik hayatın belirli bir kültürel örüntüye atıf içermesine, dolayısıyla bir kök paradigmayı ya da referans sistemini içkin olmasına değil, seküler ve dinsel kategorilerinin, olguların donuk bir fotoğrafı üzerine teori üreten modern bilim anlayışının akılcı tasarımlarını yanlışlayacak ölçüde girift ve devingen ilişkisine dayanır. Böylece gündelik hayat, bu ilişkinin deviniminden doğan alt üst oluşların, yer değiştirmelerin nüvesi olan pratikleri 
ve bu pratiklerin ortaya çıkış aşamalarını teşkil eden değerlerin, yargıların, normların ve eylem kalıplarının doğallaşmış dünyasını temsil eder. Böylece toplumsal dönüşümün izini sürmek için elverişli bir yol açar. "Bu yolla günlük hayat kalıpları, yaşama desenleri, zihniyet yapıları, dünya algıları, hayat tasavvurları ve bu sınırlarda gerçekleşen altüst oluşlar ya da sıradan farklılaşmalar açıkça izlenebilmektedir" (Subaşı, 2007, s. 3). O halde gündelik hayatı önemli kılan en temel unsur, temelinde kimlik sorunlarının da nedeni olan belirli bir kök paradigmanın bulunuyor olması ve dahası bu durumun gündelik hayatın doğasından kaynaklanmasıdır.

Gündelik hayatın seküler temellerini sorgulamak üzere ortaya çıkan bu makalenin temel amacı, 'gündelik hayatı dönüştürme fikri'ni -ya da sıklıkla kullanacağımız ifadesiyle sokağı büyüleme faaliyetini- tartışmaya açmaktır. Makaledeki tabirler ve bölüm başlıkları, gündelik hayatın iyi bir temsilini vereceğini düşündüğümüz 'sokak' metaforuna dayanmaktadır. Sokağın dokusu başlıklı ilk bölümde, gündelik hayata rengini veren kavramsal örgüye yer vereceğiz. Seküler, modern, rasyonel kavramları ve bunların türevleri açısından bizce yanlış yerleştirilmiş yapbozu yeniden kurmayı deneyecek ve gündelik hayat tartışmaları açısından kavramsal düzeyde işlevsel olabilecek alternatif bir okuma yapacağız. Sekülarizm, sekülerleşme, seküler ve dinsel kavramları bağlamında özellikle Asad ve Manzur'un tartışmalarına başvuracak, rasyonelleşme konusunda ise özellikle Ritzer'in çalışmalarına atıfta bulunacağız. Gündelik hayat konusunda ise önde gelen iki teorisyenin, Lefebvre ve De Certeau'nun çalışmalarını birlikte okuyarak gündelik hayatı dönüştürme faaliyetlerinin büyük bir bölümünü anlatmak üzere De Certeau'nun stratejik ve taktik uygulama kavramlarına stra-taktik uygulama kavramını eklemeyi önereceğiz. Sokağın bekçisi isimli ikinci bölümde, söz konusu kavramsallaştırmaya dayanarak gündelik hayatta sekülerleşmenin etkilerinden bireysel enstrümanlarla kaçışa imkân tanımayan, böylelikle sekülerliği garanti altına alan iktisat, siyaset ve hukukun konum ve işlevini tartışacağız. Bu kısımda iktisadın felsefi temellerine ve özellikle gündelik hayatla ilişkisi bağlamında tüketim kavramına dayanarak bir açıım sağlamaya, bürokrasi kavramı etrafında siyaset alanını betimlemeye ve son olarak ahlakla ilişkisi açısından hukuk alanını ele almaya çalışacağız. Sokağın büyücüsü bölümünde gündelik hayatı dönüştürme konusunda bir fail olarak ön sıralarda yer alan İslamcılık ideolojisini stra-taktik uygulama bağlamında tartışmaya açacağız. Yani İslamcılığa yaygın tartışmalardan ziyade karakteristiği açısından yaklaşacağız. Sokağı büyülemek şeklinde açımladığımız sonuç bölümünde ise büyülemenin anlamı, anlamlılığı, imkânı ve tarzı üzerine kısa bir değerlendirme yapmaya çalışacağız. Her biri müstakil bir tartışma konusu olan bu dört bölümün birleştirilerek sunulması, özellikle literatürü kısıtlaması nedeniyle makalenin temel zafiyeti olarak görülebilir. Ancak ortaya koymaya çalışacağımız argümanın anlamlılığı açısından bu birleştirmenin gerekli olduğu kanaatindeyiz. 


\section{Sokağın Dokusu: Gündelik Hayatın Seküler Temelleri}

\section{Sekülarizm, Hristiyanlık ve Modernite}

Sekülarizm ile seküler birbirinden ayrılması gereken kavramlar olmasının yanı sıra birbirileriyle ve din ile ilişkileri de girift bir niteliktedir. Manzoor'a (2008) göre çağımızın hâkim anlatılarına egemen olan ve kendisini nihai hakikatin kaynağı olarak sunan sekülarizmin temel varsayımına göre ilerleme halindeki insan zihni bilgi, etik ve kutsallığın yegâne kaynağıdır. Sekülerlikten farklı olarak sekülarizmin Hristiyanlıkla ilişkisini tespit etmek, onun dine ilişkin tutumunun ayırt edilmesinin yanında, sekülerliğin evrensel bir olgu olduğunu, insanın bilişsel yeteneklerini kutsalın belirlenmesi ve açıklanması süreçlerine dâhil ettiği her durumda söz konusu olabileceğini de gösterir.

"Sekülarizm, sık sık iddia edildiği gibi Hristiyanlığın gayrimeşru çocuğudur. Müslüman bir okuyucu için sekülerliğin sadece köken itibariyle değil özü itibariyle de teolojik olarak bağı olduğu yerin Hristiyanlık olduğu kesinlikle gözden kaçmayacak bir şeydir. Bir doktrin olarak sekülarizm geleneksel Hristiyan dogması bedenleşmeden düşünülemez, bu dogma sadece Hristiyan Tanrı kavramını tanımlamakla kalmaz aynı zamanda onun canlanışının izini süren sonsuz kurtuluşçu şiddet çevrimleri bir yana, normatif anlamda 'Hristiyan siyasetinin' ruhunun özelliklerini de verir." (Manzoor, 2008, s. 137-138).

Sekülarizmin doktrinel özelliklerini ve Hristiyanlıkla ilişkisini kavramak ve onu sekülerlikten ayırmak, sekülerliğin Batı düşüncesinde geçirdiği dönüşümü anlamaya bağlıdır. Batı düşüncesinde sekülerliğin kökleri açısından dört evreden söz edilebiliriz. Birincisi sekülerliğin pagan kökleri, ikincisi paganlığın Hristiyanlık karşısındaki yenilgisine rağmen hafızalarda duran azametli hatırasına yaslanan Hristiyan kökleri, son ikisi ise sekülerliğin bilinen iki formu olarak modern ve postmodern kökleridir. Bu süreçte seküler ile dinsel arasındaki gerilim çoğu zaman eklektik yapılar ortaya çıkarmış ve sekülerlik ifşa, şiddet, monolojik söylem gibi birtakım göstergeleri dinî uygulamalar aracılığıyla da olsa sürdürmüştür. Modern zamanlarda kamusal alanın özel alana rağmen genişlemesinde ortaya çıkan ifşa, günah çıkarmada kişiyi mahrem bir konuyu açıklamaya teşvik eder. İki kılıç kuramı ve Hristiyan Tanrı kavrayışından bağımsız olmayan bir felsefi temele yaslanmakta olan modern siyaset, teolojiden bağımsız düşünülemez. "Daha daraltılmış bir ifade ile modern zamanların seküler terörü, Hristiyanlığı tarih boyunca izleyen şiddetin mutasyonlu bir şeklidir" (Manzoor, 2008, s. 138). Monolojik söylem ise kendisini öteki üzerinden anlamlandırmakla ilgili bir durum olarak kavranabilir. Burada ötekine karşı iki temel refleks maddi güce bağlı olarak içe kapanma veya yok etme şeklinde tezahür eder.

Sekülerliğin geçirdiği bu evreler içinde sekülarizmin tanımlanması açısından kilit rol modern sekülerliğe aittir. Modern sekülerliğin başlangıcı için resmî bir tarih verilecekse, Reformasyon bunun için biçilmiş kaftandır. Luther, Erasmus'u dikkatli bir okumadan geçirmiş ve düşüncelerini benimsemişti. Ancak Erasmus'un bu düşünce- 
lerini uygulamaya koyacak bir yapıya sahip olmadığına kanaat getirerek, durumdan vazife çıkarmıştır. "Erasmus, hümanist hareketin Roma'ya açıkça meydan okumaya ve Roma'ya karşı savaş ilan etmeye kalkışmasının, Kilise'nin seküler prenslerle iş birliği yapıp hümanist harekete bir karşı-saldırı başlatmalarına ve bu hareketi yerle bir etmelerine müsait bir zemin hazırlayacağından korkuyordu" (Frankl, 2003, s. 137). Erasmus'un aksine devrimci bir kişiliğe sahip olan Luther, prenslerden destek alacağına inanmış ve 95 tezi, 1517'de Wittenberg Kilisesi'nin kapısına asmıştı. Luther, öngörüsünde haklı çıkmasına ve başkalarının içlerinde biriktirip de söyleyemedikleri şeyi radikal bir tarzda ifade etmesine rağmen, çevresinde oluşacak halkanın kendisini sürüklemeye başladığı bir hareketin lideri olup çıkmıştı. Bu nedenle de "benim kuluçkaya yatırdığım tavuktan benim de aklımın köşesinden geçmeyen yumurtalar toplamaya kalkıştı" (Frankl, 2003, s. 138) diyen Erasmus gibi erken sekülaristlerin desteğini yitirmiştir. Hümanistlerin aksine Kilise doktrinine uygun bir dindarlığa ve Hristiyan erdemine değil, doğrudan Kilise dogmalarına ve Kilise kurumuna saldıran Luther'in havarileri, prensler, tüccarlar, şövalyeler ve çiftçiler olacaktı. Bu kesimlerin şikâyet ve taleplerinin yönlendirmesi altında, bir anda evrensel Hristiyanlık fikrinin yerini alternatif bir Alman Kilisesi almış ve alabildiğine sekülerleşen yeni bir anlamlar dünyasında, 'dindarlık'ın tohumları atılmıştır. İsa'nın evrensel öğretilerini Kilise'nin denetiminden kurtarmak ve şeytanın gerçekliğin ortasında cirit atmasına göz yuman bir kaçış olarak çileciliğe son vermek için görece hümanist etkilerle yola çıkan Luther, bir anda sekülerlerin açıkça kişisel taleplerinin meşruiyet merciine dönüşmüştü. Kilise'nin Hristiyanlığı tahrip etmesi ile seküler unsurların talepleri arasında sıkışan Reform hareketi, bizzat Luther'in fermanlarıyla, -Yahudilerin ve ayaklanan köylülerin katliam cevazlarında beliren şiddet tekelinde görüldüğü gibi- erken sekülarist bir harekete dönüşmüştür. Kökleri buraya dayanan sekülarizm, seküler form ve ilkelerin politik olarak kurgulandığı ve bir ideolojik çerçeve içerisinde bütünleştirildiği bir yapıdır. Bu nedenle temel varsayımlarının, ürettiği tanımların ve sahip olduğu politik ilkelerin bir uzantısı olarak, dine karşı belirli fakat -toplumun özgül koşullarına bağlı sekülarizm yorumlarından kaynaklanan- düzensiz bir tutum sergileyecektir. Bu durum, paradoksal olarak seküler ile dinî olanın ayrıştırılamayacağı anlamına gelir. O hâlde sekülarizm, seküler ve dinsel tanımlamalarını, tekelindeki bir ödev olarak görmek durumundadır.

Modernite ise sekülarizm ile doğrudan alakalı bir proje olarak karşımıza çıkar. Modern kavramı, sekülerliğin Rönesans hümanizmi ve Reformasyonla birlikte ortaya çıkan Batı'ya özgü bir formunu anlatırken modernite, sekülaristlerin seküler form ve ilkeleri kurumsallaştırmak üzere ortaya koyduğu bir projedir. Bu, modern toplumsal tahayyülün ateizme dayandığı, kamusallığın da bu çerçevede kurgulandığı ya da din ile devletin, özel ile kamusal olanın tamamen ayrıştığı anlamına gelmez. Aksine dinî olan, bireysel ve kolektif eylemi güdüleyen kimliğin bir parçası olarak kamusal alanda yer tutmaya devam edecektir. 


\begin{abstract}
"Sekülarizmi basitçe yönetimde dinî kurumların seküler kurumlardan ayrılması olarak görmek kolay olsa da, hepsi bundan ibaret değildir. Soyut olarak koyulduğunda, bu ayrılığın örneklerini Orta Çağ Hristiyanlığında ve İslam imparatorluklarında da -ve kuşkusuz başka yerlerde de- bulabiliriz. 'Sekülarizmin' ayırt edici yönü yeni 'din', 'etik', ve 'siyaset' kavramları ve bunlarla ilişkili yeni kurallar öngörmesidir" (Asad, 2007, s. 11).
\end{abstract}

Buraya kadar yer verdiğimiz kavramların yanlış kullanımı nedeniyle ortaya çıkan teorik problemlerin, hacimli bir külliyat oluşturduğunu söyleyebiliriz. ${ }^{1}$ Bu tartışmanın önemi, seküler ile modern arasında kurulan ilişkiye, yeni tip bir modernleşme (veya sekülerleşme) önerisinin eklemlenmesinde yatar: din veya büyüden vazgeçmeden modernleşmek.

\title{
Seküler ve Dinsel
}

Dine ilişkin bir tanımın kaçınılmaz uğrak noktası, toplumsal gerçeklik olmak durumundadır. Bu nedenle, dinin bağlı olduğu koşullara paralel olarak, insanların 'dinî' olarak kategorize ettikleri şeylere ilişkin algıları ve bu algının unsurlarını bir araya getirme tarzlarını söz konusu etmek, dinî olanla seküler olanın ayrıştırılmasının ön şartıdır. 'ilk olarak, seküler ve dinsel arasındaki ilişki tek yönlü değil diyalektiktir, iç içe geçişler söz konusudur. İkincisi seküler ile dinsel arasındaki ayrım ya da sınırlar, evrensel değil tarihsel ve toplumsaldır. İç içe geçişlerin nerede başlayıp nerede bittiği ise ancak özgül koşullarda değerlendirilebilir. Üçüncüsü ise bu kategoriler bağlamında birey, sürekli bir gerilim hâlindedir. Bunun nedeni seküler ve dinsel kategorilerinin insanın bilişsel yapısına içkin olmasıdır.

"Günümüzde dindarlık var olduğu gibi, eski dönemde seküler tutumlar da var olmuş olabilir. Kutsal, sadece eski dönemlere has, sabit bir olgu değildir. Çünkü ünlü din bilimci Eliade'ın vurguladığı üzere, 'kutsal, insan bilincinin tarihinde bir aşama değil, bilincinin yapısı içinde bir unsurdur'. Dolayısıyla o, insan zihninin yapısal bir unsurudur ve insan var olduğu sürece, kutsalın tezahürü de toplumsal hayatta varlığını sürdürecektir" (M. Arslan, 2010, s. 208).

1 Berger'in sekülerleşme teorisi ve yeni dinsel yönelimlere ilişkin çeşitli çalışmalarından çıkan sonuca göre sekülerleşme, modernleşmenin kaçınılmaz bir sonucu değildir (M. Arslan, 2010). Taylor ise "sekülarizmin modernliğin başlarında Batı Hristiyan toplumunun siyasi sorunlarına - her şeyden önce yıkıcı din savaşlarına- yanıt olarak ortaya çıkmış olmasına karşın, modernleşmiş bütün gayri Hristiyan toplumlara da uygulanabilir olduğunda ısrar edenler arasındadır" (Asad, 2007, s. 12). Taylor ve Berger, Batı dışı toplumlar için benzer şeyler öneriyor. Fakat dikkat edilirse önerilerinde Taylor sekülarizmi, Berger ise moderniteyi evrensel sistemler olarak kurguluyor. Bu tip argümanların koca bir yekûn tutması tesadüf olabilir mi? Altun'un (2005) modernleşme kuramları üzerine çalışması bu soruya her zaman iyimser bir yanıt verilemeyeceğini ifade ediyor. Modernleşme kuramları, modernitenin Batı dışı toplumlar için bir amaç olduğunu ve bu toplumların her biri için farklı reçeteler bulunduğunu iddia eden entelektüel bir sistemdir. Modernleşme kuramları modernleşmeyi devrimci, kompleks, sistematik, küresel, uzun vadeli, tedrici, homojen, ilerlemeci ve geri döndürülemez bir süreç olarak tanımlamakta ve $\mathrm{ABD}$ şahsında mükemmel bir temsile eriştiğini iddia etmektedir.

2 Tekin (2003), illk Çağ, Orta Çağ ve Modern Dönem Batı dünyasında Tanrı kavramını-yedeğindeki din kavramını da dâhil edebiliriz- ve toplumsal iz düşümünü soruşturduğu makalesinde, Tanrı kavrayışının toplumsal yapı ve işlevlerle organik bir ilişki içinde olduğunu belirtmektedir. 
Seküler ve dinsel arasındaki ilişki, siyaset ve din arasındaki ilişkinin niteliğiyle kayıtlıdır. Siyasi gerçeklik, modernliğin homojen nitelikte olduğu söylemini temellendiren sekülarist ilkeleri dayatarak ya da Rawls'ta olduğu gibi örtük olarak bu ilkeleri benimseyen mutabakat yolları arayarak, seküler iktidar seçkinlerinin veya entelektüellerin birçok kriz durumunda alacağı kararı belirlemektedir. Burada seküler ve dinsel açısından iki temel sorunsal devreye girer: faillik ve niyet. Seküler bir devletin, siyasal veya iktisadi olarak gerekçelendirdiği bir uygulama, pekâlâ yurttaşların dinî duyarlılıklarla ya da dinî niyetlerle desteklediği bir uygulama olabilir. Şu hâlde bu iki kategori, sekülarizmin aralarındaki geçişliliği görmezden geldiği, ek olarak ayrımın nesnel veya evrensel bir nitelikten ziyade, ulus devletin inşasında somutlaşan ideoloji yorumuyla yakından alakası olduğu şeklinde anlaşılmalıdır. O hâlde sekülarizm, siyasi, iktisadi ve kültürel süreçler eliyle küreselleşirken, uğrak noktalarındaki özgül siyasi koşullara göre yorumlanan bir kök paradigma olarak egemenlik kurmaktadır. Özgül koşullar, hem Batı'da hem de Batı dışında ortaya konulan uygulamaları belirlemektedir. “Fransa'da hem aşırı merkezîleşmiş devlet hem de yurttaşlar seküler olmasına karşın, İngiltere'de devlet Resmî Kilise'ye bağlıdır ama yurttaşların pek azı dindardır; ABD'deyse nüfusun çoğu dindardır ama federal devlet sekülerdir" (Asad, 2007, s. 16). Göle'nin (2009) Batı dışı modernlikler kavramı ise sürecin Batı dışı coğrafyalardaki gelişimini anlatmaktadır. Ancak sekülarizm ve beraberinde gelen seküler ve dinsel kategorilerinin, bütünüyle ulus devlete bağımlı olduğu anlaşılmamalıdır. Aksine sekülarizmin gelişimine bağlı olarak bu ikisi, Soğuk Savaş sonrasında çok daha net bir biçimde uluslararası sistemin etkilerine açık hâle gelmiştir.

\section{Sekülerleşme Teorisi}

Sekülerleşme teorisi, modern toplum tasvir edilirken dinin diğer alanlara nispeten, gündelik gerçeklikteki konumuna atıfla yapılan analiz ve yorumlara dayanır. Bu bağlamda, sekülerleşmenin ne kadar kapsamlı bir değişim olduğu, değişimin özsel mi niteliksel mi olduğu, seküler ve dinseli nasıl etkilediği gibi sorular, konunun bir yönüdür. Mesela değişimin özsel olmadığını kabul ettiğimizde Asad'ın (2007) belirttiği üzere bugüne kadar seküler bir kategori olarak kodladığımız mesela milliyetçilik olgusunun dinî kökleri canlı bir şekilde taşıdığını kabul etmek gerekir. Diğer yönü ise sekülerleşme teorisi kutsala dönüş vesilesiyle sarsıldı inancıdır ki bu inanç, sekülerleşme teorisi bağlamında öne sürülen argümanların hakikate güçlü yaklaşımlar sergilediği başka inançlara dayanmaktadır. Sorunun zorlu kısmı da burasıdır: sekülerleşme teorisi ile -yeni dinsel hareketler, dinin siyasileşmesi gibi durumlarla ortaya çıkan- sekülerleşme teorisine yönelik eleştiriler arasındaki bağlantı nedir? Söz konusu eleştiriler, büyük oranda i- 'din kamusallaşıyor', ii- 'dinî inancın ve kurumların önemi artıyor' ve iii- 'din yapısal farklılaşmayı kırarak diğer alanlarla ilişkiye giriyor' önermeleri üzerine kuruludur. Bu önermeler, sırasıyla sekülerleşme teorisinin, i- 'din özelleşmişti', ii- 'dinî inanç ve kurumlar önemini yitirmişti' ve iii- 'din yapısal farklılaşma sonucunda diğer alanlardan 
kopmuştu' yargılarını içkindir. Bunun neden önemli olduğu ise gerçekte vuku bulan ve çözümlenmesi daha derinlikli bir analizi gerektiren başka bir durumun gözden kaçmasıyla açıklanabilir. Arslan'ın, süreci tasvir ederken kullandığı tipik bir cümle ile örnekleyelim:

"Weber modern toplumlardaki gelişim sürecini ve bu gelişimin ana trendi olan sekülerleşmeyi açıklarken 'büyü bozumu' terimini kullanmıştır. Günümüzde ise dinsel ve büyüsel eğilimlere ilgide artış gözlenmektedir. Sosyal bilimlerdeki son değerlendirmelerde, modernliğin getirdiği aşıı rasyonelleşmenin manevi doyum ihtiyacının arttığından ve bu ve benzeri nedenlerle dinsel bir canlanmadan ve 'kutsala dönüş'olgusundan bahsedilmektedir" (M. Arslan, 2010, s. 196).

Oysa ki dine karşı uslanmaz tavır, modern sekülerliğin içinde yer bulan materyalist ve pozitivist bakış açısının ürünüdür, sekülarizmin değil. Postmodern sekülerlik ise modern sekülerlikte apriori kabul edilen ilkeler nedeniyle görünmeyen, üzeri örtülen, özsel ve yapısal değişikliğe uğratılan dine, hatta modernliğe içkin kutsiyetin de kaynağı olan dindarlığa görünürlük kazandırmıştır. Toplamsal ve tarihsel bağlamı nedeniyle seküler ve dinselin otantik formlarını yakalamak zordur. Moderniteye ait hususiyetler ortadan kaldıııldığında bir bilgi kategorisi olarak seküler varlığını sürdürmesine rağmen, sekülere ait hususiyetler ortadan kaldırıldığında modernitenin de temelsiz kalacağı görülecektir. Çünkü modernite dediğimiz olgu, seküler bilgi, eylem ve duyarlılıkların biçimlendirdiği siyasal, iktisadi ve hukuki boyutları olan bir projedir. ${ }^{3}$ Ayrıntısına girmeden postmodernite için de benzer bir yorum yapılabilir. "Aydınlanma düşüncesinin sonu olan post-modernizm, kapitalist toplumsal örgütlenme biçiminin ve en geniş anlamda modern projenin sonu değildir, daha ziyade Baumann'ın deyimi ile 'gerçek tabiatının bilincinde olan' veya 'yanlış bilinçlilikten kurtulmuş modernite'dir" (Mert, 1998, s. 136). Dolayısıyla sekülerleşme teorisinin eski ihtişamını yitirmesinin asıl nedeni, "siyaset ve din kategorilerinin birbirileriyle bizim düşündüğümüzden daha derin bir şekilde iç içe geçmiş olduğunun anlaşılmasıdır -modern ulus devlet hakkındaki bilgimizin artmasına eşlik eden bir keşiftir bu" (Asad, 2007, s. 239).

Bu durumda, bizzat egemenler tarafından devletin simgesel yüzünü temsil eden unsurlardaki görünürlüğü bulanıklaştırılan din yok edilmemiş, sekülarizmin siyaset, iktisat ve hukuku ahlaktan arındırdığı bir çerçevede yeni tanımlamalara maruz kalmış-

3 Talal Asad'ın yaptığına benzer bir yolla seküler ve dinî olanın soy kütükleri aracılığıyla hem bu iki kategorinin sınırları hem de bunların pagan, Hristiyan, modern ve postmodern dönemle ilişkisi takip edilebilir. Bunun yanı sıra -örnekleri çoğaltmak mümkün olmakla birlikte- Rıfa'at Ali Abou-El-Haj'ın Modern Devletin Doğası ve Cemal Bali Akal'ın Modern Düşüncenin Doğuşu isimli eserlerine atıfla alternatif bir yol önerilebilir. Bu iki eser, -yazarların niyetinden bağımsız olarak- bir yandan seküler ve dinî kategorilerinin toplumsal ve tarihsel bir devinim içinde olduğunu, iç içe geçişlerin bulunduğunu ve tüm bu hareketliliğin yalnızca dış etkenlerle açıklanamayacağını göstermektedir. Öte yandan sekülarizmin daha sonra kurucu ilkeler olarak vazedeceği birtakım unsurların modern olanı öncelediğini, daha doğrusu Rönesans ve Reform süreçleriyle birlikte seküler olanın kendini yeni bir formda (modern) ifade ettiğini anlamamızı sağlayacaktır. 
tır. Sonuçta din, şeklî ve kurumsal görünümüyle algılanan, ancak varlık ve etkinliğini farklı bir yapı ve söylemle sürdüren bir nitelik almıştır. Bununla birlikte, buraya kadarki tespitlerin hiçbiri, oluşacak yeni kavramsal şemadan sekülerleşme tezini veya en azından yedeğinde bulunan kavramları ihraç etmeyi gerektirmez. Bu yeni şemada 'büyü bozumu' kavramı, yerini rasyonel eyleme bırakan dinden yoksun bir dünyayı değil; -belki daha da kötüsü- felç geçiren ve sekülarizmin omuz vermesiyle ağır aksak yürüyen dinin, kendisine ait olduğu rasyonel bir dünyayı anlatmaya başlar.

\section{Rasyonalite, Din ve Büyü}

Antik Yunan'da logos kavramı, felsefi düşüncede temel bir konuma sahipken sekülerleşme süreçlerinin farklılaşmasıyla birlikte yerini ratio'ya bırakmıştır. "Heidegger'e göre logos'un ratio'ya dönüşümü sıradan bir tercüme olarak değil de, Batı metafiziği içerisinde kavramın Greklerdeki köklü karşıı̆ı̆ından şimdiki hesaplayıcı/teknik bir düşünmeye varışının serüveni olarak anlaşıımalıdır." (Yılmaz, 2009, s. 17). Batı düşüncesi, en azından Platon'dan beri rasyonalist karaktere sahip olmakla birlikte, Heidegger'in sözünü ettiği manada bu kavramın merkezine oturduğu bir üst-anlatı oluşturacak cüreti, ilk kez Descartes'ta görmekteyiz. “Bütün biçimleriyle rasyonalizm temelde aklın üstünlüğüne inanma olarak tanımlanmakta ve gerçek bir dogma olarak ilan edilmektedir; ayrıca bireyüstü düzene ait olan her şeyin, özellikle saf entelektüel sezginin metafiziksel bilginin dışlanması sonucunu doğurmaktadır" (Guenon, 1990, s. 114). Dolayısıyla, burada söz konusu ettiğimiz akılcılık, Descartes'ın kendisinden sonraki rasyonalist veya ampirist tüm düşünürleri etkisi altına alan öznel akılcılığıyla ilişkilidir. Horkheimer'in deyişiyle, adalet ve özgürlük gibi geçmişte nesnel aklın doğasında var olduğu düşünülen amaçlar düşünsel köklerinden kopmuştur. Bu amaçlar, Batı düşüncesinin seyri içinde önemli referanslara sahip oldukları için hâlâ belli bir itibara sahiptirler, hatta bazıları anayasal metinlere de girmiş olabilir ancak biçimsel akılcıllğın iltifatına mazhar olamayışı ve sekülarizmin egemenliğinde kendilerini toplumsal gerçekliğe bağlayacak olan herhangi bir 'akıl'ın bulunmayışı nedeniyle de askıda kalmışlardır (Horkheimer, 2010). Böylece amaçlarla birlikte kutsalın silikleştiği yeni bir toplumsal yapı ortaya çıkmaya başlamıştır. Tam bu noktada dini de içine alacak şekilde geniş bir anlamda kullanılabilecek olan büyü olgusunun, toplumsal gerçekliğin temel referans sistemini kuşatma pozisyonunun sarsılmasından söz edilebilir.

"Weber dört farklı akılcılık ortaya koydu ve akılcılığın farklı toplumsal ortamlarda farklı biçimler aldığını ileri sürdü. Pratik akılcılık, insanların günlük faaliyetlerinde amaçları için en iyi araçları aradığı dünyevi bir biçimdir. Kuramsal akılcılık, pratik değil bilişseldir ve soyut kavramlar aracılığıyla gerçekliğe egemen olma çabasını içerir. Tözel akılcılık, daha büyük toplumsal değerler tarafından ve bu değerler bağlamında yönlendirilen araçların seçimini içerir. Formel akılcılık benzer bir araç seçimi içerir, ama bu kez evrensel olarak uygulanan kural, hukuk ve düzenlemelerle yönlendirilir. Batının ayırt edici ürünü formel akılcılıktır" (Ritzer, 2011, s. 89). 
Yılmaz'a (2011) göre tözcü yanlış anlamalara sebep olabilen akıl kavramının, bir unsur olarak anlaşıldığı duruma akledilebilirlik/rasyonalite denir. Rasyonalite ile büyü arasındaki gerilim, sırasıyla seküler ve dinselin tahayyül mekanizmaları olarak işlemelerinden kaynaklanır. Rasyonalitenin, oluşacak yeni kavramsal şemadaki konumu, Aydınlanma düşüncesiyle birlikte apaçık ortaya çıkar ve sekülarizmle ilişkisini ele verir. Aydınlanma aklı, özellikle de ansiklopedistlerin çalışmalarıyla -Bacon'a kadar geri götürülebilecek olan bilimsel bilginin araçsal kullanımına benzer bir tutumla- bütünüyle irrasyonel/ büyüsel unsurların olumsuz bir tarzda deşifre edilmesi yönünde bir tutum geliştirmiştir: evren, bütünüyle rasyoneldir. Romantikler ise kaygılı bir şekilde başarıya eriştiğini gözlemlediği ve tam da bu yüzden 'büyünün bozulması' şeklinde tabir ettiği aklın bu kazanımını, Tanrısal boyutun ihmal edildiği bir doğa-insan bütünlüğü açısından eleştirmekteydi. Buna mistisizmin eleştirileri de eklenince, baş harfi büyük yazılan 'gelenek' söylemi icat edilmiş ve modernin karşısına konumlandırılmıştır. Bu söylem, yine modern kodlara dayanan dikotomiler üzerinden, her türlü kötülüğün/şiddetin kaynağı olarak sekülerliği/modernliği gösterecektir.

Rasyonalitenin temel varsayımlarının, seküler şiddetin doğa, toplum ve insana uygulanmasıyla gerçekliğe dönüşme sürecine rasyonelleşme diyebiliriz. Weber'in moderniteyi toplumsal rasyonalite olarak kodlamasının da buraya dayandığını düşünüyoruz. Weberci rasyonelleşme teorisi, dört temel parametrenin belirleyiciliği altında işlemektedir. ${ }^{4}$ Ritzer'in (1998), rasyonelleşme teorisini McDonalds'a uyguladığı çalışmasında işletmenin başarısını varlıklarına bağladığı bu parametreler: verimlilik, hesaplanabilirlik, öngörülebilirlik ve denetimdir. Bunlar, akılcılaştırmanın tüm boyutlarına vurgu yapmaktadır. Mesela işlem hızının yükseltilmesi ve sonuçta daha çok sayıda ürün ortaya çıkması niceliğe, en az kaynak kullanımı ise optimum tercihlere vurgu yapmaktadır. Ritzer'e (1998) göre, akılcılaştırmanın işlemesine yegâne engel, insan tarafından ortaya konmakta, bu nedenle insansız teknolojilere geçiş ve denetimin derinleştirilmesi söz konusu olmaktadır. Bu durumda optimum araç tercihinin ancak doğalcılık algısının bir ürünü olduğu ve önceden belirlenmiş bir düzenek içinde bireyi belirli bir seçime yönelttiği sonucuna varılır. O halde modern sekülerlikle ayrıştıramayacağımız biçimsel akılcılığın, insan doğasından kaynaklanmayan, tersine toplumsal gerçekliğin inşa biçimlerinde izlerine rastlayacağımız sonuçları, gündelik hayatın sekülarizmle girdiği köklü ilişkiyi gösterir.

Bu parametrelerin temelini teşkil eden planlama, insanın Aydınlanma sonrasında kendisini Tanrı yerine konumlandırmasının sonucu ve göstergesidir. Ancak bu parametrelerin kendinde kötü bir şey olmayıp rasyonalitenin Batı'ya özgü bu formu içinde, yani seküler kurgu içinde olumsuz bir anlam yüklendiği göz önüne alınmalıdır. "Planlama denilen şey insanın şu andan sonra ne yapacağını düşündüğü en önemsiz durumlarda bile, doğal olarak söz konusudur... Modern uygarlı̆̆ın saplanmış olduğu oldukça yeni ve özel bir planlama ise göreceli olarak uzak bir geleceği göz önüne alır ve büyük ölçüde kolektif bir planlamadır... Amaçları daha iyi yaşam standartları, görünen çatışmanın yok edilmesi ve her şeyden önce ilerlemedir... Araçları sağlaması konusunda (ise) modern bilime güvenir" (Northbourne, 2000, s. 67). 


\section{Gündelik Hayat, Kültür ve Iiktidar}

Gündelik hayatın formel bir tanımını vermek zor görünüyor. Bu nedenle, gündelik hayatın dönemlendirilmesi, konumu, işlevi ve işletim sistemi üzerinden bir betimleme yapmak daha uygun gözüküyor. "Gündelik hayatın tarihi en azından üç kısım içerir: a) Üsluplar (şenlikli toplum); b) Üslupların sonu ve kültürün başlangıcı (XIX. yüzyıl); c) gündelik hayatın yerleşmesi ve sağlamlaşması" (Lefebvre, 1998, s. 43). Bireycilik olgusunun sonucu olarak, paradoksal bir şekilde toplumun diğer üyelerine bağımlı hale gelen birey, iktidar karşısında yalnızlaşmıştır. Seküler bilgi, eylem ve duyarlılıkların dinî olanı özelleştirmesi, sekülarizmin bir sonucu olarak kendiliğinden her oluşu sürecin dışına iten benlik politikasının bir parçasıdır ve gündelik hayatı şart koşmaktadır. "Seküler benlik, giyinme (ve soyunma şekillerinden), erkeklerle sosyalleşmeye ve kamusal alanda hareket etmeye varıncaya kadar, öğrenilmesi, prova edilmesi ve icra edilmesi gereken bir dizi bedensel pratiğe tekabül eder" (Göle, 2012, s. 20). Şu halde, gündelik hayatta sistemin işleyiş mantığı, 'hegemonik seçilim' olarak tanımlanabilir: günlük pratiklerin genetiği, sonsuz sayıda olası seçim arasından, hegemonyanın öne çıkardığı veya elediği seçimlerle şekillenir. Bu sürecin çıplak gözle görünmemesinin nedeni ise sekülarizmin kendisini bir ideoloji olarak değil, kültür olarak ve gündelik hayat aracılığıyla sunmasıdır. "Gündelik hayatın fenomenleri, onlara dair kavrayışımdan bağımsız görünen ve kendilerini kavrayışıma dayatan örüntüler içinde önceden düzenlenmiştir" (Berger ve Luckmann, 2008, s. 34). Gündelik hayatın sunduğu gerçeklik, her bir bireyde tezahür ettiği için doğallaşır, doğal olan bireysel ve kolektif eylem açısından olası tercihlerin ilk sırasında yer alarak özü itibariyle rasyonel kabul edilmeyecek olsa bile rasyonelleşir. Lefebvre, bu süreci kapalı devre bir sisteme benzetmektedir.

"Toplumsal ve zihinsel biçimler, kendilerini çevreleyen bir dünya içinde verili gibidirler. Sanatın, estetiğin veya estetizmin biçimleri, toplumsal ilişkilerin ritüelleştirilmiş biçimleri için de geçerlidir bu... Normal olan alışılmış hale gelir; alışılmış olan, böylelikle doğal olan ile birleşir; doğal olan da akılcılık ile özdeşleşir. Böylece bir döngü ya da kapalı devre gerçekleşir. Bu belirgin mantığın, akılcılığın yerini alan bu doğalcılığın içinde çelişkiler yok olur: Gerçek ile akılcı özdeşleşir, gerçeklik ile ideallik birbirine girer, bilgi ve ideoloji birbirine karışır" (Lefebvre, 1998, s. 50-51).

Kendiliğindenmiş gibi tasvir edilen bu süreç, modern iktidarın terbiye araçlarıyla, bilinçli bir politikanın ürünü olarak gerçekleştirilmektedir. "Disiplinsel iktidarın başarısı, hiç kuşkusuz basit aletlerin kullanılmasına bağlıdır: hiyerarşik bakış, normalleştirici yaptırım, bunların bileşik hale getirilmeleri ve bu birleştirmenin bu bileşime özgü sınav biçimi altında gerçekleştirilmesi" (Foucault, 2006, s. 255). Foucault'da disiplinsel iktidar modern iktidarla çakışan anlamda kullanılmakta ve disiplinin en önemli araçlarından olan sınav, geniş bir perspektiften ele alındığında De Certeau'nun uygunluk kavramına denk düşmektedir. Uygunluk, dil, sembol ve simgeler aracılığıyla bireyin kamusal kimliğini yöneten bir araçtır. "Uygunluk eş zamanlı olarak hem algılanma biçimimiz hem 
de boyun eğmenin sürmesinin baskıcı aracıdır; temelinde, davranışlar oyunundaki bütün uyumsuzluklardan ve sosyal çevre algısındaki bütün nitel kırılmalardan kaçınılmasını emreder" (De Certeau, Giard ve Mayol, 2009, s. 40). Tanımlarda görüleceği üzere sınav, gündeliğin alanında bireylerin belirli bir 'cevap anahtarına' uyarlanmasını sağlamaktadır.

\section{Lefebvre: Zaman ve Mekan}

Modern zamanlarda gündelik hayatın ayırt edici yönü, gerçekliğin temel boyutları olarak zaman ve mekânı seküler birer kategori olarak kurgulamasında ve zamanın stratejik değerini arttırmasında yatmaktadır. Sayısız iktisadi ve siyasi sonucu olan “hızın mekânsızlığının stratejik değeri, kesin bir biçimde mekânın stratejik değerinin yerini almıştır" (Virilio, 1998, s. 127). Sekülarizm, zaman ve mekânı ayrıştırarak farklı zamansallıklar aracılığıyla gerçekliği de bilinci de parçalı bir yapıda yeniden kurgulamıştır. "Gündelik hayat gerçekliği, bedenimin buradalığı ve mevcudiyetimin şimdiliği etrafında düzenlenmiştir" (Berger ve Luckmann, 2008, s. 35). Eylem, zaman ve mekâna refere edilebilecek bütünselliğini yitirmiştir. Bu denklemde zaman aritmetiğe, mekân geometriye, bu iki boyutlu koordinat üzerinde gerçekleşen hareket ise mekaniğe gönderme yapar. ${ }^{5}$ Üsluplar, şahsı mekâna bağımlı açıklarken, gündelik hayat bireyi zamana bağımlı kılar; mekân aidiyet kavramını çağrıştırırken, zaman yersiz-yurtsuzluğa vurgu yapar. Bu açıdan zaman, modern dönemi kinayeyle anlatmak için tek başına yetecek bir kavram olma gücüne sahiptir. ${ }^{6}$ Berger ve Luckmann'ın (2008) ifade ettiği gibi, bir bilinç yitiminden sonra kendine gelen kişinin ilk işi, saate bakarak zamanı yakalamak olacaktır. Bilinçsizlik anında birey, tabi olduğu 'zaman ritminin' sevk ve idaresine karşı bir itaatsizlik yapmış olma korkusuyla derhal toparlanıp tekmil verme ihtiyacı hisseder. Günlük hayat, büyünün sokakta sere serpe dolaştığı üslup zamanlarından beri hep var olagelmiştir. Ancak Lefebvre ve Regulier (2005), günlük hayat ile gündelik hayatı ayırmaktadır. Gündelik olma hali, günlük hayatın faaliyetleri arasında gözden kaçan

5 Newton mekaniği, Batılı dünya görüşü ve varlık tasavvurundan bağımsız olmayan seküler bir bilimsel paradigma öngördüğünden beri, modern bilimin ve Aydınlanma sonrasında ortaya çıkan sosyal bilimlerin nesnesi, tek tek olgulardan ve olaylardan soyutlandığında en temelde harekettir. Cisimlerin, toplumun, bireyin, kültürün, düşüncenin... hareketine ilişkin incelemelerin her biri farklı bir bilimsel disiplin üretmiştir. Saint Simon'un sosyolojiyi 'sosyal fizik' olarak kurgulamış olması tesadüf değildir. Aynı paradigma modern dünyada gündelik hayat içindeki bireysel ve kolektif eylemin de genetiğine işlemiştir. Sözü geçen iki boyutlu koordinat düzlemi de aynı paradigmanın Öklidci geometriye dayanmasından kaynaklanmakta ve -metafizik boyutların yokluğunu görmezden gelsek bile en azından- üçüncü boyutu ihmal etmektedir.

6 "Dinin tam zıddı dünya değil zamandır (dehr). Dehrtam olarak gelip geçicilik mânâsına gelir ve klasik İslâm'da aşkınlığın zıddını temsil eder. Zaman bütün değerleri yok eder ve hem ahlâki hem de zihni hiçliğin babasıdır. Eğer sekülarizm sadece metafizik iddialarında köktenci oluyorsa ve eğer sadece her tür aşkınlığın reddiyle aynı mânâya geliyorsa ve yine eğer sadece eon, dehr ve seculumun dışında bir şeyin var olmadığını iddia ediyorsa, o zaman kendisini sadece İslâm'ın zıddı olarak sunmaktadır ve kendisini sadece diyaloga yer bırakmayan mutlaklaştırıcı bir anlayış türüne dönüştürür" (Manzoor, 2008, s. 140). 
türdeş, tekrarlamalı ve fragmanlara ayrılmış zaman dilimleriyle ilgilidir. Ancak bu zaman dilimlerinin kendisi ya da onların rastgele geçip gitmesinin ifade ettiği şey değil, bunların ardı sıra dizilimleri, aritmetiksel tekrarın getirdiği hegemonik seçilimin eylemler üzerindeki ölçme işlevine sahip olan ritmidir. Bu zaman ritimlerine içkin yönergeler, bireyi denetim altında alarak eylemler üzerinde buyurgan bir otoriteyi temsil eder. Ancak farklı ritimler, gündelik hayatın kesintiye uğramasına neden olabilir -Lefebvre için şenliğe dönüş anlamına gelen bu halin gündelik hayatı büsbütün dönüştürmesi, devrim demektir. Bu yöndeki bir teşebbüsün başarısızlığı ise gündelik hayat egemenliğinin pekişmesi demektir.

Zamansallıkla bağlantılı olarak, ilerleme düşüncesini çağrıştıran doğrusal ve döngüsel tekrarlar konusunda da bir dönüşüm ortaya çıkmaktadır. Zamansallık, üslup zamanlarında, şenlikli toplumda doğanın döngüsüne tabi idi. Döngüsel tekrar, temel zamansal ritimdi, kümülâtif değildi ve büyüsel ögelerin kaynağıydı. Modern dönemde doğrusal tekrar, belirgin zaman ritmi durumuna geçti, akılcı yapılar içinde kümülatif ve dolayısıyla nicel, usanç verici tekrarlar ortaya çıktı. Bireyi tüm usancına rağmen motive eden tek şey ise bu doğrusallık üzerinde, aritmetiğin her adımda niceliği arttırmasıdır. Postmodern dönemde ise zaman, Ritzer'in (1998) 'akılcılığın akıl dışıı̆ı' kavramsallaştırmasına paralel olarak, bağımsız ve iç tutarlılıktan yoksun 'an'lara bölmüştür. Postmodern durumda, birey zaman bağımlı konumdan kurtulmuş olmaz, hatta farklı zamansal ritimlerin Lefebvre'ci devrime zemin oluşturma olanağı da sarsılır. Çünkü farklı zamansallıkların ortaya çımasının ön koşulu, zamanın bütünlüklü olarak algılanmasıdır.

"Postmodernite tarihi dün ile yarın arasındaki "an"a indirger; zaman homojen, evrimsel, amaçlı ve düzenli bir şey değil, eşitsiz, çapraz, çok katmanlı ve hizası bozuk bir şey olur çıkar. Dolayısıyla hiper-uzam yaratılabilen ve yok edilebilen bir şeydir. Zaman postmodern mantalite çerçevesinde düzenliliğini kaybetmenin yanı sıra bir biri ile ilintisiz "an"lar haline gelmektedir. "An"lar arasında bu bağlamda bir tutarlıık olması gerekmez... Her "an"da diğerinden bağımsız olarak bir başka anlam ve gerçeklik inşa etmek mümkün hale gelmektedir" (Tekin, 2011, s. 16).

Mekânsal düzlem ise bireyi bedensel tahakküme açık hale getirir, burada temel sorunsal aidiyettir. Çünkü bireyin sahip veya ait olduğu bir mekân yoktur, her durumda tâbi olduğu bir mekân vardır. Buradaki aidiyet basit anlamılla mülk edinmeye değil, referans sistemine atıf yapar. "Mekân kavramı boş bir yere değil, dışlama ve içermenin, kabul edilebilir olan ile yasak olanın sınırlarının belirlendiği, toplumsal ilişkilerin üretildiği bir yere atıfta bulunur" (Göle, 2012, s. 24). Çünkü mekân, gündelik hayat uygulamalarının ön koşulu olarak, uygulamayı refere eden bir takım normlar içerir.

\section{De Certeau: Stratejik ve Taktik Uygulama}

De Certeau'nun gündelik hayat analizlerini, Lefebvre ile birlikte okumak ilgi çekici açılımlar sağlamaktadır. Analizlerini en kaba haliyle iki sınıf üzerinden -erk sahipleri 
ve ezilenler- formüle eden De Certeau için gündelik hayatın bireyi iki boyutlu (zaman ve mekân) algılaması karşısında yapılabilecek şey çok sınırıdır -hayatın strateji veya taktikler üzerinden kurulması. Bu açıdan erk sahipleriyle ezilenler aynı sekülarist etkiye mahkûm gözükmektedir. Ancak zamana karşı göreli bir direnç kazanmış olan erk sahipleri stratejik uygulamalar ortaya koyar. Bu uygulamalar karşısında ezilenler (tek tek bireyler) ise Lefebvre'in (1998) tabiriyle taklitçi, sefil, kıskanç ve düzenbaz taktiklere başvuracaktır. Lefebvre, gündelik hayatın birbirine önemli ölçüde karşıt iki kanadı olarak sefalet ve büyüklükten söz ediyor. Sefalet, yoksunluk, usanç verici görevler, aşağılanmalar (sınıfı toplum karakteri ve iş bölümü nedeniyle herkes bir diğeri tarafından aşağılanma riski ile karşı karşıyadır), değersizleşen yaşam ve ritüeller olarak algılanıyor. Büyüklük ya da süreklilik ise bedenin, mekânın ve zamanın sürekli uyarlanmasını ifade ediyor. Strateji ve taktiklerin tanımı için doğrudan De Certeau'ya başvurmak yerinde olur.

"Strateji uygulaması, her şeyden önce belirli bir aidiyet olarak çerçevesi çizilen bir alanın varlığını (mekân üzerinden belirlenmiş organik bir bağı) gerektirir. Bu alan, ilişkilere, belirgin bir biçimde dıştan bakabilecek bir idareyi mümkün kılan, bu idarenin zeminini oluşturan alandır. Politik, ekonomik ya da bilimsel akılcılık (rasyonalizm) işte bu stratejik model üzerine kurulur... Taktik, uygulama alanı olarak ötekinin alanına sahiptir. Taktikler, ötekinin alanına, bu alanı bütünüyle kapsamadan, bu alana belirli bir mesafede kalmayı da başaramadan yavaş yavaş, parça parça sızar... Aidiyet, mekânın zamana karşı zaferidir. Aksine, taktik, mekânsız olduğu için, zamana bağımlıdır ve kendi çıkarına kullanabileceği olasılıkları yakalamak için sürekli tetiktedir... Günlük yaşamımızdaki pek çok alışkanlık, tutum ve uygulama (okumak, konuşmak, dolaşmak, pazara gitmek ya da yemek yapmak) taktik türündendir... Oysa stratejiler, ait olunan bir mekân ya da bir kurum aracılığıyla korunan ve onları bu biçimde destekleyen erkle ilişkilerini, nesnel hesaplamalar ardına saklar" (De Certeau, 2008, s. 54-55).

Günlük hayatın sıradan bir uygulamasını örnek verelim: okuma, çoğu zaman otorite tarafından üretilen veya otoritenin onayladığı metni gerektiren bir etkinlik olmuştur. Hatta okuma etkinliğinde bireye -en azından 'okuma'yı öğrenene kadar- rehberlik edecek bir de öğretmen memur kılınır. Daha da ileri giderek bireyin doğru okuyup okumadığını anlamak için sınav benzeri araçlar ihdas edildiğini de ekleyebiliriz. Ancak tüm 'yazma stratejilerine' rağmen ezilenler, metnin alternatif okumaları için öğretmenin gözünden kaçmak, kopya çekmek, hızlı okuma teknikleri kullanmak gibi basit veya metnin yeniden inşası gibi karmaşık bir dizi taktik geliştirir -ileride bu ikisini ayıracağız. Günümüzde doğrudan bu taktiklerin dayandığı imgelem denetim altına alınarak, özerk okuyuşların önü kapatılmaya çalışılmaktadır.

\section{Stra-taktik Uygulama}

Dikkatli bir inceleme, gündelik hayat teorisyenlerine atfen yaptığımız gündelik hayat betimlemesinde bu makalenin de ana odağını teşkil eden bir eksiklik olduğunu fark edecektir. Buraya kadar, erk sahibi ve ezilen sınıf ile sırasıyla bunlara ait -belki de bun- 
ları var kılan- stratejik ve taktik uygulamadan söz ettik. Ancak De Certeau'nun analizlerinde, erk sahipleri ve ezilenler arasında, Lefebvre'in ısrarla vurguladığı devrimci eylem ve faili belirgin değildir. Cantek'in (2008) aktardığı bir başka gündelik hayat teorisyeni Agnes Heller için bu faile ihtiyaç yoktur, toplumun dönüştürülmesi için Marx'ın kullandığı bağlamda yabancılaşmayı aşarak kendisini dönüştürecek olan birey, denklemin çözülmesi için yeterlidir. Lefebvre ve De Certeau'nun analizlerine kıyasla fazla iyimser hatta liberal duran bu yorum, sorunu aşamamaktadır. Bu da büyüleme edimi açısından stratejik ve taktik uygulamaya ilişkin okumanın başlangıcı olan fakat sonu olmayan umutsuz bir tablo çizdiği anlamına gelmektedir. Bu gerekçelerle, sokağın büyücüsüne atfedebileceğimiz uygulama tipini tespit etmek üzere, taktik uygulamayı alt birimlerine ayırmayı deneyeceğiz. De Certeau'nun strateji ve taktik kavramına ilişkin açıklamaları üzerine yapılacak bir yorum, strateji ve taktiğin alt birimlerine erişme imkânı tanır. Stratejinin kendi içinde farklı tarzda kullanımlarını görmek için erkin kapsamına ve bu kapsamlardaki dağılım şekline bakmak gerekecektir. Asıl konumuz olan taktikleri ise iki alt birim şeklinde okuyacağız. Lefebvre ve De Certeau'nun çalışmalarının birleştiği yer de tam burasıdır. İktidardan gelen caydırma, şartlandırma ve ödüllendirme stratejileri karşısında basit ve savunmacı bireysel eylemi salt-taktik; zaman bağımlı konumunu mekânsal aidiyet düzeyine taşımaya çalışan kolektif eylemi ise stra-taktik olarak tanımlayacağız. Basit ve karmaşık 'okuma' eylemini ayıracağımızı belirtmiştik. Stra-taktik, kolektif bir yapı olan düşünce okulu ya da akımlarının metni yeniden inşa girişimdir.

Stra-taktik uygulamada, taktik kodlar büyük ölçüde aynı kalırken uygulamanın tarzı ve salt-taktik uygulamaya oranla daha uzun vadeli getirileri olması nedeniyle stratejik uygulamayı andırır, ancak değildir. Bu tip uygulamanın varlık koşulları, doğrudan sekülarizmin işaret ettiği değerler ve egemenlik alanından doğar. Normal şartlar altında bireyler, Lefebvre'in kapalı devre sistemi ve De Certeau'nun taktik uygulama kavramsallaştırmasının anlattığı şekilde davranacaktır. Ancak stra-taktik, ezilenlerden belirli bir sınıfın temsilcisi/hâmisi rolüyle ve genellikle organize bir şekilde, erk sahipleriyle farklı biçimlerde mücadeleye girişen kolektif bir yapıya gönderme yapar. $\mathrm{O}$ halde stra-taktik uygulama ve faili, sınıfsal ilişkilere tâbidir. Stra-taktik uygulama, stratejik yönelimi nedeniyle ideoloji ve iktidarla doğrudan temas kurar, onu kültür olarak algılamanın üstünde bir düzeydir bu. Ancak bu tanışıkığın sonuçları, bir noktadan sonra faili ve temsilcisi olduğu sınıfı aşan sonuçlar üretir. Bu sonuçlar, ezilenleri sekülarizmin belirlediği yeni şartlara bağımlı kılar. Böylece stra-taktik, bir yandan ezilenlerin taktik repertuarını zayıflatırken, öte yandan onları sekülarizmin ürettiği yeni tanımlar dairesine taşımaktadır. Bu durum, en iyi ihtimalle ezilenlerin bir biçimde stratejiye atfedilebilecek her türlü uygulamaya ait umutlarının tükenmesiyle, daha kötüsü ise stratejik taleplerin yerini memnuniyete bırakmasıyla sonuçlanacaktır -stratejik taleplerin meşruiyeti ise ayrı bir sorundur. 


\section{Sokağın Bekçisi: Stra-taktik Uygulama Alanları}

Lefebvre (1998), haklı olarak üslup zamanlarından kopmuş modern toplumu 'bürokratik yönlendirilmiş tüketim toplumu' olarak tanımlamaktadır. Bu isimlendirme iktisat, siyaset ve hukuk alanlarını taramaktadır. Bunlar, stratejik hamlelerden kaçış için bireysel enstrümanların yetersiz kaldığı güdümlü alanlar olarak, üç boyutlu koordinat düzlemine benzemekte ve bireye, gözetim ve denetimin ıskalamayacağı şekilde kurgulanmış belirli bir konum tayin etmektedir.

"Rasyonalist zihniyetin herhangi bir ahlak yahut riyaset nizamı düşünemeyişi... çağdaş negatif hürriyetçiliğin ve hür iktisadi faaliyet ile hukuk önünde eşitliğin kaynağı olan aynı yüzyıllar süren sürecin bir cephesi, bir veçhesidir. Aynı evrimin bağlantılı süreçleri olarak, pazar ekonomisi, akılcılık okulu, liberal siyaset doktrini ve kurumlar ile çağdaş bilim ortaya çıktı; bunların kendilerini ayrı ayrı kabul ettirebilecekleri ise düşünülemez" (Kolakowski, 1999, s. 212).

Üç alan içinde en kaçınılmaz olanın hukuk olduğunu belirtmekle birlikte hukukun modern öncesi toplumlarda sahip olduğu kurucu işlevini yitirmiş olduğunu ve görevi iktisada devrettiğini belirtmek gerekecektir. "Iktisadi hayatın temel düzenleyici ilke olduğu kabul edilen günümüz modern toplumunda kapitalizmin temel kuralları değişmeden kalırken; üretim, fordist üretimden esnek üretim tarzına... evriliyor" (A. Arslan, 2009, s. 147). Fakat iktisat, siyaset ve hukukun aynı düzlemin farklı boyutları olarak belirlenmesi aralarındaki bağın yok sayılmasını gerektirmez, tersine işlevleri arasında zorunlu bir bağıntı bulunur.

\section{Siyaset}

Rasyonalite, geçmiş tüm toplumlarda şu veya bu biçimde var olmuş olabilir, ancak "biçimsel akılcılık, insanların belirli bir amaç için optimum araç arayışının kurallar, yönetmelikler ve daha büyük toplumsal yapılar tarafından biçimlenmesidir" (Ritzer, 1998 , s. 48). Ancak bu süreç, bir cümlede ifade edildiği kadar pürüzsüz gerçekleşmez. Mesela optimum araç, bireylerin keşfettiği değil, öğrendiği araçlardır. Bu öğrenmebağımlı pozisyon, gündelik hayatın egemenliğini her an pekiştirmesi olarak sonuçlanır. Bu süreçte bağımlılık, bürokraside, ${ }^{7}$ bilim ve teknolojiye bağıı iktisadi ilişkilerde ve son olarak da bireyin bir çeşit organik bağ geliştirdiği bir diğer bireyde tezahür etmektedir. Ritzer'e (2011) göre bürokrasi, biçimsel akılcılığın bir sonucudur ve özetle, erkin bir tür dağılımını anlatır. Bu dağılımın ihdas ettiği kurumsal roller dolayımıyla bürokrasi, bürokratlar, profesyonel elitler ve yurttaşlar açısından bir demir kafese dönüşür. Seküler (ulus) devlet, bürokratik bir örgütlenme modeline sahiptir. Bu modelin temel

7 "Bürokrasi büyük oranda modern batı toplumunun yarattığı bir kurumdur. Daha önceki toplumların da örgütsel yapıları olmasına karşın... geleneksel toplumlarda görevliler işlerini liderlerine kişisel bağIılık temelinde yerine getirirlerdi. Bu görevliler şahsi olmayan kurallardan çok kişisel kaprislere tabiydi. İşgal ettikleri makamlarda kesin tanımlı yeterlilik alanları yoktu, kesin bir konum hiyerarşisi yoktu ve görevliler bir konuma gelmek için teknik eğitim almak zorunda değillerdi" (Ritzer, 1998, s. 47). 
özellikleri, merkezi ve kalıcı bir vergi sistemine sahip olması, düzenli bir askeri güce dayanması, yasa koyma ve meşru şiddet uygulama tekelini elinde tutması ve profesyonel bir elitin iktidarı biçiminde örgütlenmesidir (Habermas, 2001). Bürokrasinin demir kafesi, seküler devletin iktidarını kırsal kesimlerinde bile bir dizi kurum aracılığıyla temsil etmektedir. Açıktır ki, De Certeau'nun taktikleri, siyasal alanın bekçiliğini aşamayacaktır. Şu halde siyasal alan stra-taktiğin ilk uğrağıdır.

\section{Hukuk}

Sekülaristlerin yaslandığı ön kabul ve tipik dikotomiler hukuk ile ilgili çözümlemelerde de kendisini hissettirmektedir. Schmitt (2005), modern devlet kuramının bütün önemli kavramlarını ilahiyat kavramlarına dayandırmakta, ancak sekülerleştiğini belirtmektedir: "olağanüstü halin hukuk için taşıdığı anlam, mucizenin ilahiyat için taşıdığı anlama benzer" (Schmitt, 2005, s. 41). Schmitt'in egemenlik ile ilgili genel görüşleri -konumuz açısından- temelde iki şeyi işaret eder: birincisi sekülerin kendisini dini bir formda yeniden ürettiği, ikincisi ise seküler ve dini olanın aynı şişedeki hava ile su gibi sürekli ayrık duracağıdır. Buradan Schmitt'in söylemek istediğinden daha önemli bir şey çıkarabiliriz: sekülarizmin egemenliğinde hukuk ile ahlak ayrışmıştır. Dolayısıyla hukuk, modern öncesi toplumlarda ilahiyatın işlevini yerine getirmekte, bireyin tüm eylemlerini kuşatmaktadır.

"Modern hukuk düzenleri esasen öznel haklarda temellenir. Bu haklar bir gerçek kişiye, kendine ait imtiyazlarıyla tanzim ettiği için yasal bir hareket sahası açarlar. Böylelikle hak sahibi kişiyi ahlaki emirlerden veya başka türden talimatlardan azade kılar... Öznel hakları devreye sokmakla modern hukuk geleneksel hukuk düzenlerinden farklı olarak belirtik biçimde yasaklanmış olmayan her şeye izin olduğu doğrultusundaki Hobbescu ilkeyi geçerli kılar. Böylece hukuk ile ahlak ayrışırlar" (Habermas, 1999, s. 62).

Hukuk kurallarının düzenlenmesi ve uygulanmasında, tarih boyunca iki temel eğilim tespit edilebilir. Aralarındaki fark hukukun tanzim ve uygulamasının, anayasa niteliğindeki ilkelere dayanıp dayanmamasında ortaya çıkar. Weber'in, anlama ve açıklama kavramlarını işlevsiz kılan araçlara ya da dini kanaatlere dayanan hukuk sistemlerini, biçimsel akılcılık açısından irrasyonel bulacağını tahmin etmek zor değil. Anayasal niteliğe sahip, biçimsel akılcılığın temel parametreleri açısından anlamlı araçlara ya da yasaya dayanan hukuk sistemleri ise rasyoneldir. Bu kompozisyonun ilerleme gibi bir dizi seküler varsayıma eklemlenmiş olduğu dikkatlerden kaçmayacaktır. Manzur'a (1990) göre, seküler hukukun temelindeki insan ve haklar gibi en temel kavramlar bile sekülerdir.

"Laik hareket, din ilkesini devlet olmanın Avrupa tarihindeki ilkesi olmaktan çıkarmayı başardıktan sonra, ilk olarak seküler ulus-devletin temellerini atmıştır. Dünyanın sekülerleştirilmesi şeklindeki aynı sürecin bir sonraki aşaması da seküler devlete bağımsız bir ahlaki sistem sağlamaktı. Nitekim insan hakları konusunun ortaya atılmasıyla seküler düşünce kendi siyasi ahlak anlayışını keşfediyordu" (Manzur, 1990, s. 37). 
Bu sistem içinde bireyin taktikler aracılığıyla bir kaçış alanı açması imkânsız görünüyor. Ancak stra-taktik için de iç açıcı şeyler söylemek zor. Uygulamaların pratikte gideceği en ileri aşama, seküler tanımların üzerine yeni bir kurgu yapmak olacaktır. Bu da hem strataktiğin failini hem de temsil ettiği kitleyi bu tanımlar eliyle gelen anlam şemasına taşır.

\section{iktisat}

İktisadın modern zamanlardaki konumu verili değildir. Çünkü yalnızca toplumsal gerçeklik düzeyinde değil, bilimsel bir uğraş olarak da iktisadın başka alanların etkisinden kurtulması olgusuna yabancı değiliz. "iktisat çok önceden değerden bağımsız rasyonalite, mantıkçı pozitivizm ve formalist matematik tarafından istila edilmişti, şimdi devir değişmiş ve iktisat diğer alanları istila etme pozisyonuna gelmiştir" (Yılmaz, 2009, s. 101). Bu durum, postmodern duruma geçişte sekülarizme halel gelmediğini, hatta bir noktaya kadar modernleşmenin sonuna ilişkin söylencelerin teorik tartışma düzeyinde kaldığını, sokağın bekçileri aracılığıyla ideolojik arka planın sürdürüldüğünü gösteriyor.

"Batılılaşma olarak modernleşmenin sonu, gerçekte, modernleşme projesinin sonunu değil, değişimini ve/veya daralmasını ifade ediyor. Esnek modernleşme veya neo-modernleşme diyebileceğimiz bu yeni modernleşme anlayışı da eskisi kadar ideolojik... yerelliklere, farklı kültürlere izin vermesine rağmen, esnek modernleşme anlayışının da evrensel kabul ettiği değerler var: piyasa rasyonalitesi ve şekli demokrasi" (Çınar, 1997, s. 52).

Dolayısıyla cari iktisat, felsefi zemin olarak rasyonaliteye dayanmaktadır. İktisat politikalarının siyasal süreçlerle ilişkili olarak ortaya konması ve hukuk aracılığıyla bağlayıcılığının sağlanması ise egemen koordinat düzleminin rasyonel kurgusunda bir sorun olmadığı izlenimi uyandırmakta, öte yandan tüm yurttaşları kuşatmaktadır. "Weber kapitalizmi biçimsel olarak akılcı sistemlerden biri olarak gördü ve kapitalizmin maddi, kafes benzeri karakterine olağanüstü net bir tanım sundu: bugün kapitalizm, bireyin içine doğduğu ve kendini bireye en azından bir birey olarak, yaşaması gereken değiştirilmez bir düzen şeklinde sunan uçsuz bucaksı bir kozmostur" (Ritzer, 2011, s. 92). Bu kozmosta, bireysel alanda meydana gelen krizlerin etkisiyle modern birey, sezgisel olarak bir bekçinin nefesini ensesinde hissetmesine rağmen, durum sezginin ve hislerin ötesine geçememektedir. Çünkü profesyoneller, modern bireye maddi başarısızlıkların nedenini kendisinde aramasını telkin edecek araçlar açısından oldukça zengin bir repertuar oluşturmuş durumdadır. Popüler kültür aracılığıyla yaygınlaştırılan kişisel gelişim, başarı öyküleri gibi temaları içeren basılı ve görsel araçlar büyük ölçüde buraya yaslanmaktadır. Somutlaştırmak üzere iktisat ile ilişkili gözüken, ancak üç düzlemce de taranan bir örnek olarak tüketici kavramının gelişim seyrini kısaca takip etmek, sürece ilişkin ipuçları sağlayabilir. 
19. yy sonlarında sömürgecilik yerini emperyalizme bırakırken tüketici kavramı ortaya çıktı. Sömürgeci faaliyetlerin zayıflaması 1. Dünya Savaşı sonrasında bu yolla açık ham madde kaynağı ve pazar konumundaki ülkelerin bu niteliğini kaybetmesiyle sonuçlandı. Pazar ihtiyacı ve 1929 ekonomik kriziyle tüketici kavramının anlamını restore etmek zorunlu hale geldi ve pratikte reklamcılığa eklemlenmiş bir tüketim ideolojisi şekillenmeye başladı. Bu kavramla birlikte tüketim kültürü kavramı da sosyal bilimler literatürüne girdi ve nihayet Soğuk Savaş'ın başlarında tesadüfî olmayan bir şekilde ABD başkanı Kennedy tarafından "tüketici hakkı" kavramı kullanıldı. Bir araştırmaya göre, ${ }^{8} 1970$ 'de tüketici kavramı çeşitli uluslararası düzenlemelere girdi, 1972 'de Paris Avrupa Topluluğu görüşmelerinde tüketici hakları gündeme getirildi ve 1975 'de tüketici hakları beyannamesi niteliğinde bir metin ortaya çıktı. Fark edileceği gibi 'tüketici' kavramsallaştırması üç alanla da irtibatlı olarak ortaya çıkan ve gündelik hayatta iktisat aracılığıyla rol alan, bireyin ve toplumun ontolojik konumlanışını yeniden düzenleyen ve kendisiyle kurulan her temasta yeni değerler aktaran ideolojik bir arka plana sahiptir. Kültür endüstrisi kavramı etrafında oluşan literatür, bireyin taktik uygulamalarla iktisadın çizdiği eksenden kaçamayacağını göstermeye yeter. Stra-taktik ise tüketicinin haklarını koruma altına alacak veya bu konuda yasal düzenlemeler yapacak uygulamaları anlatır -ki bu uygulama, en temelde tüketici tanımının içselleştirildiğini gösterir ya da bununla sonuçlanır.

\section{Sokağın Büyücüsü: İslamcılık}

Sokağı büyülemek gibi bir ödev, seküler paradigmanın dışında kalan yönelimlerin sorumluluk alanına girmektedir. Liberalizm, sosyalizm veya başka bir seküler ideoloji açısından gündelik hayatın dönüştürülmesi, onun seküler temellerinin altüst edilmesi gibi bir amaçtan çok uzaktır. Fakat sekülarizmin küresel çapta egemenliğini tesis ettiği süreç boyunca, farklı coğrafyalarda karşılaştığı 'büyüsel' direnç noktalarını (varsa) tespit etmek ve tartışma konusu yapmak da geniş bir külliyatı gerektirir. Şimdilik olası tek fail, İslamcılık gibi gözüküyor. Bu nedenle sekülarizmin, bu coğrafyada karşılaştığı varsayılan en temel direnç noktası olan İslamcılığı, stra-taktik bağlamında sokağı büyüleme ödevi açısından tartışmanın gerekliliğini vurgulamak durumundayız. Böylece İslamcılığın tarihi boyunca sürdürdüğü taleplerin ve gösterdiği eylemliliğin gerçekte paradigmal bir dönüşüme işaret edip etmediği; ikinci olarak gündelik hayatı kesintiye uğratacak bir niteliğe sahip olup olmadığı soruları cevaplanabilir.

8 Bu verilerin alındığı "Tüketici Hukuku Ders Notu" başlıklı makalenin tüm hakları yazarı Erman Eroğlu'ya (2011) aittir ve makale, yazarı tarafından Türk Hukuk Sitesi kütüphanesinde yayımlanmıştır. 


\section{Islamcılık ve Sekülarizm}

Tanımlarının çokluğu ve belirsizlikleri arasında vurgu yapılan temel bir noktaya referansla "dindarlık, bireyin dinsel yapıyla kurduğu bağlılık düzeyinin subjektif bir ifadesi" (Subaşı, 2002, s. 24) olarak ifade edilebilir. Seküler din algısının ürünü olarak dindarlık, şeklî ve kurumsal unsurların alabildiğine görünürlük kazandığı fakat kurucu ilkelerin sekülarizme eklemlendiği bireysel bir tecrübedir. ${ }^{9}$ Bu tecrübenin bireyi aşarak siyasal bir nitelik edindiği, söz konusu şekil ve kurumsallığın farklı biçimlerde kamusal alana taşınmasını anlatan kolektif boyutu ise İslamcılıktır. Özellikle de postmodern durumda dindarlığın ve İslamcılığın bu nitelikleri, 'zarfın mazrufu aştığı', bilgi, eylem ve duyarlılıklar düzeyinde bütünselliğin yerini amaçsızlığın ve anlamsızlığın -tam anlamıyla kaosun- aldığı yeni biçimler almıştır. İslamcılık eleştirisi, siyasi bir proje olarak İslamcılığın kaybettiğini dillendiren oryantalist veya ona paralel yerli entelektüellerin eleştirilerinden farklı bir zeminde yürütülmediği takdirde, -eleştirilerin doğruluğundan bağımsız olarak- malumu ilamdan öteye gitmez. Makalede, İslamcılığın doğrudan kökenleri, fikri altyapısı ve uygulamalarının tarzına yönelik kısa bir soruşturma yapma niyetindeyiz, bu nedenle reel politik duruma atıfta bulunduğumuzda bile dikkatlerin uygulamanın tarzına ve referans sistemine yoğunlaşmasını bekliyoruz.

“Türk muhafazakarlarının, İslamcılığı terk ettikleri nokta 'metne dönüş iddiası'dır. Muhafazakarlık hayatı önceleyerek İslamcıların asla ulaşamadığı toplumsal kesimlerde destek bulmuştur. Bu anlamda gerçekten de İslamcılar, iktidara geldikten sonra İslamcılıktan vazgeçmiş değil, İslamcılı̆ı̆ın siyasal iddialarından vazgeçerek iktidar sahibi olmuşlardır" (Bezci ve Miş, 2012, s. 7).

Mevcut literatür, eleştirilerini büyük ölçüde İslamcılara yöneltmektedir. Ancak İslamcılık tartışmasında, sekülarizm açısından faillik ve niyet, failini çoktan aşmış öncelikli bir konudur. Faile yapılan vurgu, ancak değerlerle ilgili analizlerde araçsal olarak kullanıldığında anlamlı olabilir. Tam da bu nedenlerle bizim burada yapmak istediğimiz tartışmanın, siyasal arenadaki kapışmalar açısından başarı veya başarısızlık şeklindeki değerlendirmelerden uzak, öze ilişkin bir tartışma olduğunu tekrarlamak gerekmektedir. ${ }^{10}$ İslamcılıkla ilgili tanımların muğlâk olduğu ve tartışmaların polemik şeklinde cereyan ettiği metinlerin, henüz dört başı mamur bir İslamcılık analizi yaptığını söylemek güç görünüyor. Bezci ve Miş'in (2012), kategorize ettikleri dört tip İslamcılık

9 Din bir kere seküler bir çerçevede kurgulandıktan sonra zamansallığa bağımlı olarak sayısız din algısı, dini kategorisi, dinsel tanımlaması ve Subaşı'nın (2002) saydığı ve sayısı arttırılabilecek olan dindarlık tipolojisi tespit edilebilir.

10 Bezci'nin mevcut iktidar durumuna ilişkin analizlerini paylaşmak durumunda oluşacak düğümün çözüleceği nokta, iktidar ve egemenlik kavramsallaştırmalarının birbirinden ayrıştırılmasına dayanır. Egemenliğin aksine parlamenter sistem açısından iktidarda olmanın seküler değerlerle açık bir uzIaşı anlamına gelen uygulamalar üretmesini, seküler değerlerin sınıf tarafından benimsenmesi takip edecektir. İslamcılığın, 1980 sonrasında küresel tırmanışa geçen liberalizm-muhafazakârlık eklemlenmesinin bir uzantısı olarak bugün gelmiş bulunduğu konum, Luther'in reform sürecinde yaşadığı ve Frankl'ın enfes bir yorumunu sunduğu gerilimi hatırlatmaktadır. 
algısı, ihtiyaç duyduğumuz analiz açısından iş görebilir. İslamcılığın (i) toplumsal algılanışı, genel olarak toplumun özel olarak Müslümanların mağduriyet koşullarının iyileştirilmesi, (ii) siyasal algılanışı, Türkiye tecrübesi özelinde düşünüldüğünde CHP ve Kemalizm antipatisi üzerinden şekillenen takıntı düzeyindeki iktidar yönelimiyle Müslümanların durumunun iyileştirilmesi, (iii) düşünsel algılanışı, Batı uygarlığıyla düşünsel olarak hesaplaşarak İslam medeniyetinin temel dinamiklerini ihya veya inşa etme çabası, (iv) bireysel algılanışı ise seküler din algısının doğal sonucu olarak bireyin dini olanı öznel bir hadiseye indirgemesinden farklı olarak bireyin Müslüman kimliği ve beraberindeki pratikleriyle kamusal alana renk verecek bir aktör olması anlamına gelmektedir. Bu kategorileştirmenin görece kapsayıc bir nitelikte olmasının yanı sıra, aralarındaki vasatın siyasal bağlam olduğunu ve aslında İslamcılık serüveninin çoğu zaman siyasal algılanışına şahit olduğumuzu söylemek mümkündür. Diğer taraftan söz konusu siyasal kavramı; iktidar odaklııı, şiddet tekeli, dinî olanın araçsal kullanımı ${ }^{11}$ ve dost ve düşman gibi siyasal kategorileri ulus düşüncesi temelinde inşa etme konularında açığa çıkan, sekülarizme özel bir anlam içerir. "Siyasallığın, iktidarı ele geçirerek iddialarını toplumun tümüne dayatma olarak algılandığı bir toplumda özelde İslam'ın, genelde herhangi bir inanç veya düşünce biçiminin siyasallaşmasından korkmak ve bunu tehlikeli bulmak anlaşılabilir gözükebilir" (Mert, 1998, s. 99).

Ulus devlet içinde, Batıcı-laik kesimlerle genlerine işleyen 'aldım verdim, ben seni yendim' oyununda sınır tanımayan İslamcılık, ulus aşırı krizler söz konusu olduğunda sınırdaki tellere takılıverir. Bunu net olarak görebileceğimiz iki örnek sayılabilir, ilki İslamcılığa özgü iken ikincisi dindarlığın Batılı tipolojileri için de geçerlidir. Birincisi, yekpare veya yegâne bir İslamcılık yoktur ve her bunlardan her biri İslam coğrafyası söz konusu olduğunda en az bir gösterge üzerinden kendi hâmiliğini vurgular. Bunun en tipik örneğini, milliyetçilik üzerinden anakronik bir şekilde yapılan Osmanlı tarihi okumalarında görmekteyiz. İkincisi, bağımsızlık mücadeleleridir -ki zaten İslamcılık da böyle bir sürecin eşiğinde ortaya çıkmıştır.

"Halklar bağımsızlıklarını kazanma veya koruma mücadelesi verirlerken, Tanrıya karşı bir tür sadakat, bir dini aidiyet siyasi kimliklerinin kurucu bileşenlerinden biri olmuştur. Sonrasında bunun nasıl yozlaşabildiğini de gördük: Kuzey İrlanda ve eski Yugoslavya'da olduğu gibi dindarlık geçip gider ve geriye sadece şovenizm kalır, fakat bu kimliğin varlığı yaşayan bir inancı da besleyebilir. Seküler dünyada Tanrı́nın yeni mekânı burasıdır" (Taylor, 2006, s. 186).

11 "Batılı muhafazakarlar, postmodernizmin yarattığı sorunlardan sonra topluma çeki düzen vermek ihtiyacıyla 'Tanrı öldüyse de canlandırılıp' siyaset kuramının din ve inanç ile birlikte toplumsal hayatın düzeninde rol oynaması gereği üzerine kafa yoruyorlar. Dikkat edilirse bu noktada önemli olan toplumsal düzendir, Tanrı́nın olup olmadığı sorusu bile bu koşullar altında hükümsüzdür; var veya yok, toplumsal nizam için ve bu açıdan var sayılacaktır. Bu Müslümanların dikkat etmesi gereken bir husustur; önemsedikleri dinleri mi, mevcut toplumsal düzenin aynen devamı veya o düzende yer (söz değil) sahibi olmak mı? İkinci kaygı ön plana çıktıkça toplumumuzda sekülerleşme bu sefer İslam adına ve İslamcılar eliyle devam edecektir" (Mert, 1998, 125). 
Sekülarizmin egemenliğinden önce savaşı kazanan tarafın iktisat, siyaset ve hukuk üretme biçimini kendi referans sistemine dayandırmaması -günümüz tabiriyle masada kaybetmesi- istisnai bir durumken, sekülarizmin egemenliğinde bu durum, kurumsallaşmış, istisnası bulunmayan, devrimlere bile pabuç bırakmayan bir nitelik kazanmıştır. ${ }^{12}$ İslamcılığın siyasal bir ideoloji olarak sivrilmesini seküler bir gösterge olarak almayı bir kenara bıraksak bile, siyasal alana tekabül eden ilke, söylem ve uygulamaların seküler bir anlam şemasını a priori kabul ettiğini görmezden gelemeyiz. ${ }^{13}$ Ayırt edilmesi gereken şey, siyasallığın, zaten İslam'da var olan siyasalığın bir adım öne çıkarılması olmadığı, seküler siyasetin bir sonucu olduğudur. ${ }^{14}$ Modern sekülerliğin aksine postmodern durumda kültürel görecelilik ve herhangi bir düşünce sisteminin kendi coğrafyasında anlamlı olabileceği kanısı, İslam'ı yeni bir tanımlamayla belirlemiş ve bu tanımlama İslam dünyasında da içselleştirilmiştir. "Bunun bir nedeni, İslam dünyasının kendini dışarıdan tanımlayan bir düşünüş çerçevesini sorgulamaksızın kabul etmesi, diğer nedeni ise içinde bulunduğu çağın tasavvuruna direnç göstermekte birçok bakımından zaaf içinde bulunmasıdır" (Mert, 1998, s. 117). İslamcılığın Osmanlı Devleti'nin son dönemlerinde bir siyasal akım olarak ortaya çıktığı zaman ortaya koyduğu söylem ve taleplerin, Osmanlı bakiyesi toplumlarda nasıl karakterize edildiği, sokak savaşı yıllarında ne tip bir projeye sahip olduğu, Soğuk Savaş'ın sona erme sinyalleri verdiği

12 Gündelik hayatın yerleşip sağlamlaştığı modern dönem, "devrimci girişimlerin her başarısızlığından sonra, gündelik hayatın nasıl daha da belirginleştiğini gösterecektir. Gündelik hayat, bu başarısızlığın nedeni ve sonucudur" (Lefebvre, 1998, s. 43). Bu açıdan dini ya da ulusal niyetlerle yapılan savaşlar incelendiğinde, nihayetinde ortaya çıkan yapının seküler paradigmayla uyumlu olduğu görülecektir. Stra-taktiğin temel yönelimleri açısından post-komünist ülkelerdeki demokratikleşme süreçleri, Soğuk Savaş ile 11 Eylül arası dönemde Orta Doğu ülkelerindeki İslamcı Hareketler ve son olarak Arap Baharı incelenmeye değer veriler sağlayacaktır.

13 "Il. Abdulhamid döneminin Namık Kemal ve Ziya Paşa gibi İslamcı edip ve aydınları ile, Şehbenderzade Ahmed Hilmi, Şeyhülislam Musa Kazım ve Said Halim Paşa, Babanzade Ahmed Naim, Mehmed Akif (Ersoy), İsmail Hakkı (İzmirli), İsmail Fenni (Ertuğrul) ve Şemseddin (Günaltay) gibi belirli bir Osmanlı İslamcı eliti, İslam’ın 'mani-i terakki' olmadığını, aksine, bilimi, düşünceyi telkin ettiği halde, zamanla Müslümanların bu yolu bırakıp skolastik düşünceye kapılarak geri kaldıklarını anlatmaya özellikle ihtimam göstermişlerdir. Onlar, genelde İslam aleminin, özelde Osmanlı İmparatorluğu'nun gerilemesinden mutlakiyet rejimlerinin ve geleneksel İslam'ın sorumlu tutulması gerektiğini düşünmüşler, gerçekte İslam'ın insan hürriyetini baskı altına alan hiçbir rejime açık olmadığını izaha çaIışmışlardır" (Ocak, 2010, s. 167). 'Ateş çemberinden geçilen bir dönem' tabirinin, İslamcı söylem ve çıkışların olası muarızlarını mazur gösterip göstermemesi veya ilk dönem İslamcı elitin böyle bir mazerete ihtiyaç duyup duymaması hatta hakıılık payları olması, bu makalenin ilgi alanı dışında kalmaktadır. Tespit etmeye çalıştığımız şey, alıntıda görüleceği gibi İslamcılığın seküler paradigma üzerinden inşa edilmesi olgusudur.

14 'Zaten İslam'da var' söylemi üzerinden karikatürize edebileceğimiz olgunun envanterini çıkarıp yorumlamak ilginç sonuçlar ortaya çıkarabilir. İslamcı literatürün büyük bir yekûnunun bu olgu üzerinden şekillendiğini görmek ayrıca şaşırtıcı olacaktır. Burada Hasan Hanefi ile Muhammed Abid elCabiri (2011) arasındaki tartışmaları bir örnek olarak zikredebiliriz. Kitapta, diyalog, köktendincilik, laiklik, liberalizm, demokrasi, çoğulculuk, modernlik(ler), Fransız Devrimi ve Aydınlanma gibi pek çok konudaki tartışmada dikkat çekeceğimiz nokta -özellikle de laiklik tartışmasında billurlaşan- seküler kodlarla konuşma hususudur. 
1980 'li yıllarda ve sona erdiği 1990'lı yıllarda hangi söylemleri ürettiği daha doğrusu söylemlerini nasıl revize ettiği ve nihayet 11 Eylül sonrasında nereye evrildiği soruları, yukarıdaki argümana netlik kazandıracaktır.

\section{İslamcılık ve Gündelik Hayat}

Gündelik hayatın seküler temelleri, seküler/gündelik ile dini/uhrevi arasındaki gerilimde kendisini gösterir.

"Gündelik ve uhrevi olan arasında hüküm süren bu mücadele alanı ve yeniden tanımlayarak dönüştürme operasyonu yalnızca İslamcı ideolojiyi değil, büyük ideoloji ve anlatıların hüküm sürdüğü her sosyal bağlamı kapsamaktadır. Sekülerleşme ve ona dair ritüeller de bu gerilimin su yüzüne çıktığı önemli alanlar olarak kavranabilir" (Akşit, Şentürk, Küçükural ve Cengiz, 2012, s. 77).

Bu gerilimin sonuçları arasında, gündelik hayatın siyasal niteliğinin artması, ideolojilerin seküler ve dini olanın aşınan sınırları arasında kavramsal bir zeminden yoksun kalması, gerilimin doğal sonucu olarak seküler ile dinsel olanın söylem ve tarz düzeyinde birbirine eklemlenmesi sayılabilir. Bu durum, mesela İslamcılık ile sekülarizm geriliminde şartların eşitlendiği anlamına gelir mi? Sekülerleşme tezinin yanlışlanması (çöküşü değil daha baştan yanlış kurgulanmış olması) ve seküler ve dinselin soy kütüğüne ilişkin çalışmalar olmasaydı bu durum eşitlikten öte İslamcılığın kazanımı olarak bile nitelendirilebilirdi. Fakat sekülarizm için bu gerilimde sonuçlar (kayıp ya da kazanç) yalnızca nicelikle ifade edilirken, İslamcılık açısından sonuç tamamen öze ilişkindir. ${ }^{15}$ İslamcılığın sekülerliği, varlığının temel koşullarını seküler politik ilkelerin zemin teşkil ettiği bir süreçte ortaya çıkan yeni siyaset, iktisat ve hukuk yapma -bunları ahlaktan ayrışmış olarak yapma- tarzlarına bağlaması anlamına gelmektedir. Sorunu karmaşık hale getiren şey ise sekülarizmin kavramsal çerçevesine gösterilen sadakatle, İslamcı tutumların kendisini her düzeyde Batı'ya özgü olanın karşıt ucunda konumlandırması arasındaki çelişkidir. Göle'ye (2012) göre, Müslüman olmanın aksine İslamcı olmak, düşünümsel bir performans gerektirir, farklılığı işaret etmek üzere simgesel malzemelerin kullanımını beraberinde getirir. "İslamcıların Meclis, üniversitedeki derslikler, televizyon programları, plajlar, opera salonları ve kafeler gibi aynı modernlik mekânlarını paylaşmaya başlaması, ama karşıt bir İslamcı benlik oluşturmaları bakımından bir tanıma sorunu ortaya çıkmaktadır" (Göle, 2012, s. 104).

15 Söz konusu gerilimin seküler ve dinî kategorileri bağlamında farklı parametreler açısından inanç, ibadet, ekonomi, siyaset gibi alanların yalnızca İslamcılık bazında değil bireysel düzeyde de ampirik olarak değerlendirmesi önemli ve güncel veriler sağlayacaktır. Bu konuda ayrıntılı veriler için bkz. (Akşit vd., 2012). İnanç ve ibadet konusundaki ampirik verilerin değerlendirildiği iki pasajı örnekleyelim: "Gündelik yaşamda kendisini 'inançlı' olarak tanımlayan pek çok bireyin, gündelik hayatın akışı ve temposu içinde dinî vecibelerini yerine getirememesi bir gerginlik nedenidir" (Akşit vd, 2012, s. 206), “Her ne kadar bazı kişiler bu ayrıştırmanın (seküler/dünyevi ve kutsal/dini) doktriner düzlemde yapılamayacağını söylese de günlük hayat pratikte bu ayrışmayı dikte etmektedir" (Akşit vd., 2012, s. 240). 
Bu sorun, kamusal mekânın kurgulanışı ile ilgilidir. Taylor'a (2006) göre kamusal alan, kapitalizm ve demokrasinin yanında, Batılı toplumsal tahayyülün temel bileşenlerinden biri olarak modernliğin de merkezinde bulunan sekülarizm tarafından biçimlendirilmiştir. Toplumsal tahayyül olarak işleyen sekülarizm, ideolojik çıplaklığıyla değil, kültürel olarak görünürlük kazanır. Bu durumda sekülarizmin farklı yorumları aracılığıyla tesis edilen bir kamusallık söz konusu olduğunda bile, farklı bir ideolojinin simgeler dolayımıyla görünürlük kazanma çabası, ilgili yorumun tahammül eşiğine bağlı olarak, bir noktadan sonra tehdit olarak algılanacaktır. Çünkü kamusal alanda hegemonik seçilim söz konusudur ve kelimenin ilk anlamıyla sekülarizmin onayından geçmiş her temsil, seçkinlik olarak algılanacaktır. Sonuçta İslamcılık, Göle'nin ifade ettiği tanıma sorununu, -iktisadi, siyasi ve hukuki süreçlere kurumsal müdahaleler yoluyla- stra-taktik uygulama biçiminde çözmek zorunda kalmaktadır. Çünkü "seçkin sınıfın bir üyesi olmak, niyetlerinden bağımsız olarak, giderek iki alanın (kutsal ve din dışı) ayrışmasına neden olan bir laikleşme sürecini harekete geçirir" (Göle, 1997'den aktaran Özdalga, 2007, s. 125). Tartışmanın diğer boyutu ise kamusal alanda simgesel temsil çabasının meşruiyetinin sorgulanmasıdır. Gerçekte gündelik hayatın seküler temellerini altüst edecek failliğin, prematüre nüveleri bile seküler olanın ayrıştııılmasına katkı sağlayacak bir eğilimi temsil etme niyeti taşır, en azından taşımalıdır. Oysa İslamcılık, -kamusal alanda simgesel temsil de dâhil olmak üzere- söylem ve projelerini modernitenin temel varsayımları üzerine inşa ettiğinden, böyle bir imkândan yoksun görünmektedir.

\section{Sonuç: Sokağı Büyülemek}

Sokağı büyülemek, bir dizi soruyu beraberinde getirir. Makalede büyüleme ediminin anlamı, tarzı, anlamlılığı ve imkânı gibi sorulara verilebilecek olası yanıtların zeminini inşa etmeye çalıştık. 'Sokak' ve 'büyü' arasında kurduğumuz bağıntıya, birinci bölümde kavramlar, ikinci bölümde gerçeklik üçüncü bölümde ise faillik ve niyet açısından yaklaşımlar getirdik. Buna göre, gündelik hayat icat edilmiş bir geçekliktir. İnsanlık tarihinde 'doğal' bir devinim olarak seyreden seküler ve dinsel gerilimi, modernliğin başlarında, sekülarizmin bir ideoloji olarak ortaya çıkmasıyla sonuçlanacak olan eşikleri bir bir aşmıştır. Gündelik hayatta, kültür formunda karşımıza çıkan ve toplumsal tahayyüller şeklinde iş gören sekülarizm, seküler ve dinsel olanı yeniden tanımlamış, moderniteyi günlük hayattan gündelik hayat devşirecek bir proje olarak hayata geçirmiştir. Gündelik hayat bir çalışma alanı olarak keşfedilene kadar, bu projeye sadık bir 'ürün olarak sosyal bilimler', seküler ve dinsel konusunda da bir dizi teori ortaya koymuştur. Gelinen noktada, bu teorileri örtük bir şekilde kabul ettiği için, teorilerin esas çöküş gerekçesi olan seküler ve dinsel gerilimini de 'dine dönüş' şeklinde yanlış kodlayan eleştirilerle karşı karşıya bulunuyoruz. Makalede bu kavramsal sorunları aşmak 
üzere görece farklı bir kavramsal şema kurgulamaya çalıştık. Sekülerleşme teorisini ve aynı zamanda eleştirilerini haksız bulan bu kurguda, makalenin temel kavramları da düzeltildi. Sonuçta, büyünün bozulması, dinin toplumsal gerçeklikten çekip gitmesiyle değil, seküler ve dinselin aşınan sınırlarıyla ilgili bir kavrama, büyüleme ise gündelik hayatın seküler temellerinin altüst edilmesine dönüştü. Ancak altüst etme kendiliğinden ortaya çıkacak bir fiil değildir: Faillik, niyet ve bunların yedeğindeki başka değişkenleri gerektirir. Bu nedenle, faillik (bilinç: büyülemenin anlamlılık ve imkânı) ve niyet (bütünlük: büyülemenin anlam ve tarzı) açısından denkleme giren değişkenlere ilişkin bir değerlendirme ile makaleyi sonlandıracağız.

Büyüleme, sıradan bir dönüşümü veya yöntemsel farklılaşmayı değil, paradigmal bir kopuşu anlatır. Bu yüzyılın büyük savaşlarında ve Aydınlanma sonrası toplumsal devrimlerde bile bu mahiyette bir örnek ortaya çıkmamıştır. Bunu, savaşın ve devrimlerin olanca şiddetine ve ağır bilançosuna rağmen değişmeyen, yorum farklılıklarıyla kendisini yeniden üreten seküler paradigmaya ve onun ürünü olan gündelik hayatın yapısına bakarak anlamak mümkündür.

"Üretim ve tüketim arasında, yapılar ve üst yapılar arasında, bilgi ve ideoloji arasında belirlenen üretim ilişkileri (kapitalist üretim ilişkileri) içinde bir geri besleme (anlık, geçici denge) vardır... Gündelik hayat, geri beslemenin toplumsal yeri olarak tanımlanır... bir denge yeridir; aynı zamanda tehdit edici dengesizliklerin ortaya çıktığı bir yerdir. Böyle bir toplumda devrim, insanlar gündelik hayatlarını sürdüremez hale geldiklerinde başlar. İnsanlar gündelik hayatlarını yaşayabildikleri sürece, eski ilişkiler yeniden oluşur" (Lefebvre, 1998, s. 38-39).

Makalede söz konusu toplumsal hareketlerin failliklerinin nerede durduğunu, strataktik kavramıyla okumaya çalıştık: Erk sahiplerinin strateji uygulamaları, kurumsal roller dolayımıyla gerçekleşir, ezilenlerin bunlar karşısındaki taktik uygulamaları da bireyin savunma mekanizmalarına gönderme yapar. Bu ikisi arasında bir ara kategori olarak konumlandırdığımız stra-taktik uygulama ise bireysel kaçış taktiklerinin işlemediği iktisat, siyaset ve hukuk alanlarında gerçekleşen kolektif eylemlerdir. Stra-taktik uygulamanın repertuarı, taktikler kadar zengin değildir -farklı zeminlere sahip olan toplumsal hareketlerin ve 'muhalif' ideolojilerin benzer yöntem ve araçlar kullanması da bundandır. Ancak stra-taktiğin yaygın iki davranış tipolojisini tespit edebiliriz. Birincisi, -self oryantalizme benzer şekilde- savunma amacıyla hâkim paradigma üzerinden kendisini yeniden tanımlamak, ikincisi ise -mış gibi tabi olmaktır. Her iki tipolojide de 'kabul görme', 'savunma' benzeri niyetlerin en temelinde aslında 'zaman bağımlılığı aşma' güdüsünün yattığını görebiliriz. Ancak her ikisi de egemenliğin pekişmesinden başka bir seçenekle sonuçlanmaz. Diken (1998), Freud'un anti-Semitizm'e cevaben Monoteizm ve Tektanrılı Dinler adlı eserinde, Musa Peygamber'in Mısır kökenli olduğunu savunurken aslında "Yahudi yoktur" yargısına varan bir argüman ürettiğini söylüyor. Benzer şekilde "Pascal'dan yola çıkarak Žižek, birçok ideolojinin sadece insanlar 
bunlara bilinçsizce inandıkları için değil, ama inanıyorlarmış gibi yaptıkları için işlerlik kazandığını söylüyor" (Diken, 1998, s. 71). O halde yönelimlerini stra-taktik uygulama yoluyla ortaya koyan faillikler, niyetlerinden bağımsız olarak, sekülerliği toplumsal direnç odakları arasına elleriyle taşımaktan, sekülarizmi yeniden üretmekten başka bir şey yapmış olmayacaktır.

Büyülemenin anlamlılığı, en temelde 'sokağı büyülemek' söyleminin tüm uzanımlarına ilişkin farkındalıktır. Burada ahlaki bir zemin ortaya çıkar, çünkü duygu, bilgi, eylem ve duyarlııkların bütünlüğü ya da parçalanması söz konusudur. Bu açıdan Mestrovic'in (1999) duyguötecilik kavramı, failliğe ilişkin önemli ipuçları taşımaktadır.

"Çağdaş Batı toplumları, sentetik sanki-duyguların benlik, ötekileri ve bir bütün olarak kültür endüstrisi tarafından geniş çapta manipülasyonunun temeli haline geldiği yeni bir gelişme safhasına giriyor. Çağdaş bireyin, atalarımızın bildiğinden daha çok bildiği konusunda modernistlere katılıyorum, ama modernist teorisyenlere karşı eylemin ortaya çıkması için bilginin yeterli olmadığını savunuyorum. Eylem, duygular ve akıl arasında bir bağlantı varsayar, işte bu duyguötesi toplumlarda bu bağlantı kopmuştur" (Mestrovic, 1999, s. 51-52).

Hodgson (2001) ise Batı'nın geçirdiği dönüşümü, onun bütün farklı cephelerini kapsayacak bir kavram aracılığıyla, teknikleşme ile okumaktadır. Hatta modern ile premoderni birbirinden ayıran temel hususiyetler olarak 'rasyonel' ile 'geleneksel' kavramlarının bile teknik anlamlar taşıdığını söylemektedir. "Teknikleşme gibi bir terim, herhangi bir cepheye üstünlük atfetmeksizin sürecin tüm veçhelerini tarafsız biçimde kapsayacaktır" (Hodgson, 2001, s. 110). Bilgi ile ideolojinin karıştığı bu süreçte, teknik bilgi değersel bilginin, teknik uygulama ve onun çıtıları da düşünsel zeminin yerini almıştır. Bu yer değiştirmenin sonucunda, anlam dünyaları yeniden kurgulanmıştır.

"Ahlakın anlam düzeyinde uğradığı mahiyete ilişkin değişim, Müslümanların giderek tüketici kitle olmalarını da kolaylaştırmaktadır. İslam'ın israf olarak tanımladıklarından birçoğunun bugün ihtiyaç olarak görülmesinin sebebi bu olmalıdır" (A. Arslan, 1997, s. 36).

Oysaki farklı ideolojiler/inançlar arasında, kavramlar ontolojik bağlamından soyutlanarak yer değiştiremez. Özellikle de bilginin (vahiy) bilfiil varlık/hayat (sünnet) olarak ortaya çıktığı İslam'da, bu tamamen anlamsız bir yer değiştirme olur -ki aslında bu, stra-taktik uygulamanın mahir olduğu bir iştir. Sonuç olarak sokağı büyülemek, faillik ve niyet açısından tüm değişkenlerin birlikte işletildiği bir uygulamayı gerektirir. 


\title{
Enchanting the Street: Investigating the Secular Foundations of Everyday Life
}

\author{
Sedat Doğan*
}

Through critiques of modernity, a situation of doubt toward the meta-narratives has been created. It would not be wrong to say that everyday life studies as an extension of this doubt. In researching everyday life, Şahin and Balta (2001) mention three basic inclinations. The first is Marxism, the second is Berger and Luckmann's phenomenological approach, and the third is the American micro-sociological tradition. The last approach has been further divided into two inclinations; as symbolic interactionism by Mead and Goffman and as an ethno-methodology by Garfinkel. Everyday Life represents a world in which the values, judgements, norms, and forms of actions that underlie the practices are accepted as "natural". So, it has a convenient way for researching on social transformation. "In this way, the moulds, life patterns, mental structures, world perceptions, and world visions of everyday life as well as the upheavals and changes experienced within these borders may be clearly observed" (Subaşı, 2007, p. 3). The point of this article is to question the secular foundations of everyday life and discussion in regards to 'the idea of changing everyday life'. The expressions and titles used in this article are based on the metaphor of a "street," which we believe give a good representative of everyday life. In the first chapter, "The Pattern of the Street," secular, religious, secularism, theory of secularization and rationalization are discussed in a conceptual framework. Furthermore, we have recommended an alternative conceptualization of everyday life within the context of Lefebvre and De Certeau. In the second chapter, "The Street's Watchman" we discuss situation and function of politics, law and economics in everyday life by using the above mentioned conceptualization. We assert these three fields as wathmen who blockade individuals and ensure the secular foundation of everyday life. In the chapter, "The Street's Enchanter" we open the discussion up to the Islamist ideology, which appears in the forefront as an actor in changing the concept of Everyday Life. In the final chapter, "Enchanting the Street" we attempted to assess the meaning, meaningfulness, possibility and styles of enchanting.

* Res. Assist., Erciyes University, Department of Philosphy.

Correspondence: sd_dogan@yahoo.com, Erciyes University, Department of Philosphy, Talas, Kayseri / Turkey. 
To consider secularism and Christianity to have the same roots, provides an understanding of approach to secularism about religion. Furthermore, this shows that secularity is at stake in every situation in which human mentality is involved in the definition and expression of the sacred. Four phases may be observed in the West when analyzing the roots of secularity. The first phase revolves around secularity pagan roots; the second, its Christian roots which appeared and institutionalized during the council; and the other two pertain to modern and post-modern secularity which are well-known formations of secularity. However secularism is a doctrinal structure that appeared along with modern secularity which then re-defined both secular and religious concepts within an ideological context. It is necessary to point out that secularism's relationship with Christianity is more than simply a historical event, it is a theological context. Manzoor (2008) states that by closely looking at secularism, a relationship between Christianity's savior, the concept of a God-incarnate and apocalyptic visions can be observed. As such, secularism is has the ability to perpetuate a number of signs and indicators particular to itself which stem from this connection between religion and even the eclectic structures into which it has entered. The most distinct of these is the characteristic of "betrayal." Secularity makes this characteristic felt in a very predominant manner in one of the most foundational rituals: the confession of sins. Despite the public sphere being a private sphere in modern times, betrayal encourages people to bring confidential issues out into the open through confessing sins. If an official history is to be given for the beginning of modern secularity, then the Reformation should be considered as its starting point. Frankl (2003) relates that it was Luther who unintentionally became the pioneer of secularization. Along with this, secularity and secularization as a human situation may have been an issue for non-Western societies in any period of history. However, secularism is particular to the West alone because it is an ideological structure which appeared during modern secularity and its roots existed in Renaissance humanism, Reformation and Enlightenment. According to Asad (2007), both in Medieval Christian and Islamic societies, it was possible for institutions which separated the secular and religious to exist, however distinguishing feature of secularism is its defining new religious, ethnic, and political concepts, as well as rules related to them. So it has redefined the secular and religious categories. Tekin (2003) claims the concept of god (in addition to religion) has been in an organic relationship with the social structure and functions in the Western thought.

The separation or limits between the secular and religious were historical, not universal. Where one began to interfere with the other however may only be evaluated under specific conditions. Secondly, the relation between the secular and religious is dialectic, not one directional. Thirdly, within these categories' context, the individual is continuously in a stressful position. For this reason, as Eliade states, it is directly human's cognitive structure (Eliade, 2003 cited in M. Arslan, 2010). The relation between the secular and religious is bound to the attribute of the relation between 
politics and religion. Secularization theory depends on its relation with and location in the daily realities of religion. As such, questions like "how comprehensive of a change is secularization?" and "how has this change affected the difference between secular and religious?" are one side of the discussion. The other side however, pertains to the belief that "secularization theory has been shaken up by a return to the sacred." Yet, this belief paradoxically depends on the presumption that the arguments put forward by secularization theory are true. However, the reason behind secularization theory's loss of its previous grandeur is "realization that politics and religion intertwine with each other more deeply than we supposed - this is a discovery that accompany the increase in our knowledge about modern nation state" (Asad, 2007, p. 239). Furthermore theories of secularization and modernization should be read cautiously. As Altun (2005) states, these theories contain many modernization projects for nonWestern societies and Gole's (2009) concept of 'non-Western modernities' describes this process of modernization.

The process of secularization has progressed with in tandem rationalization. As Yılmaz (2009) cites from Heidegger, the transformation to the logos of ratio indicated a radical change in Western metaphysics. The final phase of this transformation is treated by Descartes with his invention of the subjective intelligence, and as Guenon (1990) states, intelligence has been presented as a dogma. As such, goals like justice and freedom which exist in the nature of one's objective mind, even though they still may act to preserve one's dignity because they hold important references inside the course of Western thought, they no longer hold any sway in connecting themselves to social reality (Horkheimer, 2010). Rationalization, also in the Weberist understanding, is fundamentally connected to secularization. Weber presents four different types of rationalism. These are practical rationalism, theoretical rationalism, substantial rationalism, and formal rationalism, with this last type being distinguished in that it is a product of the West (Ritzer, 2011). Formal rationalism explains that the choice of vehicle is independent of value and depends on universal rules, laws, and arrangements. Ritzer (1998) mentions four parameters for this rationalism in his work where he applied the theory of rationalization to McDonald's: efficiency, calculability, predictability, and control. But as Northbourne (2000) express these parameters are not bad in itself but they have obtained current substance from formal rationality. From this discussion's perspective, Rationalization's importance is everyday life's foundational principle of the mass's only contact point with secularization being rationalization and should be guided by means of these parameters.

Lefebvre and Regulier (2005) make a distinction between everyday life and daily life. "The history of daily life contains at least three parts: (1) Styles (festive societies); (2) the end of Styles and the beginning of culture (9th century); and (3) the establishment of everyday life and its consolidation" (Lefebvre, 1998, p. 43). The privatization of secu- 
lar knowledge, activities, and sensitivity is a part of everyday life's politics. Until the secular self, in both its dressed and undressed forms, is able to act in the public arena and women are able to socialize with males, it will be no more than a physical practice requiring learning, rehearsal, and performance" (Göle, 2012, p. 20).

Secularism does not present itself as an ideology, but as a culture and by means of everyday life. Even the fact that ordinary humans have attitudes associated with the highest ideological values, through everyday life's secularist principles they take on a fictitious association. "The phenomenon of Everyday Life is earlier organized into a pattern which is seen independent from the comprehension of them and impose themselves on the comprehension" (Berger, \& Luckmann, 2008, p. 34). Because the reality presented by Everyday Life are manifested in every individual, it become normalized; and that which is normal becomes rationalized and the first choice in the terms of individual and collective practices. Lefebvre (1998) compares this process to a closed circuit system. This process, which portrays itself as a self-stemming process, is realized through modern power's tutelage as a product of a conscious policy.

According to Foucault (2006), tests are one of the most important means of discipline, and when considered from a wide perspective, they correspond to De Certeau, Giard and Mayol's (2009) concept of availability. An individual's identity in public life is managed through availability by language, symbols and icons. Seen in this light, tests express a specific "answer key" to adaptation for individuals within their daily life. Reading De Certeau's analyses of Everyday Life together with Lefebvre yield interesting results. De Certeau (2008) formulates his analyses based on two classes: those with power and those who are oppressed. For him, an individual is very limited in what he can do against a two dimensional (time and location) perception of Everyday Life. Specifically, the only thing he can do is build a life based on strategy or tactic. According to Virilio (1998), the strategic value of speed's lack of location, which has an uncountable number of economic and political results, has taken the place of the strategic value of location. This situation means that time has become the main parameter in the appearance of social classes.

Tekin (2011) states that by dividing time into moments independent of each other, a meaning void of integrity and reality is created, particularly for individuals with a post-modern mentality. Thus, while those with power, who have gained a relative resistance against time, exert strategic initiatives; those who are oppressed by these initiatives will resort to imitative, underhanded, jealous, and deceitful tactics, as understood by Lefebvre. These two classes, those in power and those who are oppressed, are known by their strategic and tactical implementations, respectively. In De Certeau's analyses however, it is not explicit that Lefebvre is a revolutionary actor or agent. As Cantek (2008) states, Heller believes there is no need for such an actor. This is the point where both Lefebvre and De Certeau's works converge, and this is where 
we will put forward a conceptualization: basic and apologetic actions by individuals in opposition toward the strategies of owners of power is salt-tactic implementation; whereas collective actions which attempt to bring a topic dependent on time to the spatial position are stra-tactic implementations. Under normal conditions, individuals will behave in a way explained by Lefebvre's closed-circuit system and De Certeau's tactic implementation concepts. Stra-tactic implementation, however, refers to a collective personality represented by a particular group of oppressed individuals which then enters into a struggle against those with power. In that case, stra-tactic implementations and their agent are subject to class relations. Because of their strategic orientation, stra-tactic implementations come into direct contact with ideology and power. After a specific point however, the results of this acquaintanceship produce further results which transcend the actor and representative class. These results render those who are oppressed to be dependent on the new political, economical, and legal conditioned imposed by secularism.

Lefebvre (1998) says that modern society has been cut off from time of styles and describes it as a "bureaucratic society of controlled consumption". This description comprises the areas of economy, politics, and law. Kolakowski (1999) states specific concepts relating with these areas like market economy and liberal politics are different parts of the same process and not be separated from each other. However morality falls into a different class and according to Habermas (1999) morality diverges from law. According to Manzur (1990), even the most basic concepts of secular law like 'human' and 'rights' are secular. Besides, Schmitt (2005) bases all the important concepts of the modern theory of the state on secularized theological concepts. Certainly this is true for economy and politics, so in terms of piety, there is no chance to intervene in them because "piety is a subjective expression of an individual's level of adherence to established religious structure" (Subaşı, 2002, p. 24). But these areas are controlled mechanisms which individuals instruments are not enough to provide an escape from strategic attacks. For example individuals struggle to transcend the barriers of the public sphere.

According to Taylor (2006) the public sphere which is shaped by secularism is one of the main components of the Western social imagination. These three-dimensional resemble a coordinate plane and designate a specific position for an individual. The founding function of law in pre-modern societies has been lost and has transferred its duties to economics. "Accepted as the basic organizing principle of economic life in today's modern society, the rules of capitalism remain unchanged" (A. Arslan, 2009, p. 147). The end of modernization as westernization is not the end of any project. "Although it allows localization or different cultures, the concept of flexible modernization have universal values: market rationality and representative democracy" (Çınar, 1997, p. 52). Eroğlu (2011) gives the story of the invention of the 'consumer'. This 
invention shows how these areas secularize the everyday life through redefinition of the individual. In this article, these areas appear in front of us as areas of stra-tactic implementation. By means of secularist principles, these constructed areas are also the center of stra-tactic implementations. Therefore, if it remains an area which secularity in society has not reached, it will also secularize by means of stra-tactic applications. In other words, from the perspective of enchanting the street, all possible problems will be tangled in these areas which designate flow and pace of everyday life. The underlying cause of these problems can be seen in the tension between the secular and the religious. In terms of religious people, the essential cause of tension is not being able to fulfil their religious obligations within the flow and pace of everyday life (Akşit, Şentürk, Küçükural, \& Cengiz, 2012).

According to the results of our discussions, enchanting the street is a job that the modern/secular ideology cannot do. This means that, in terms of liberalism, socialism, or another secular ideology, everyday life's transformation is no more than the reform of secularity through moderate or harsh methods; however, its secular foundations will remain intact. Non-Western societies will only have the choice of being destroyed or transformed. For this reason, we have given space to Islamism, which is seen as the "street enchanter" of the Islamic World. As Bezci and Miş (2012) state, today Islamism has come to power by relinquishing its political claims. This situation is due to the secular nation-state characteristics of the bureaucratic organization model which Habermas (2001) explains. These characteristics impose secular principles as apriori patterns of thought, as can be seen in the discussions of Hanefi and Cabiri (2011). Apparently for Islamists political claims have become less significiant than the status quo and having a say in the political order. "As the secondary concerns become more prominent the secularization of our society will continue by Islamists and in the name of Islam" (Mert, 1998, p. 125). Ocak (2010) mentions similar thoughts for the last period of Ottoman Islamic intellectuals. On the other hand as Göle states "being a member of the elite, regardless of intentions, gradually the two fields (sacred and secular) cause decomposition of a secularization process in motion" (Göle, 1997 cited in Özdalga, 2007, p. 125).

In this article, we have discussed Islamism as well as its relation to secularism and everyday life in the context of a stra-tactic implementation. Enchantment does not describe an ordinary transformation or administrative differentiation, but instead describes a paradigmatic bridge. An example of this nature has not appeared in even the great wars of the previous century or in the social revolutions which have taken place after the Enlightenment. Despite the violence and heavy costs of these wars and revolutions, the secular paradigm has reproduced itself with different interpretations but without a change to the actual paradigm. However, its product, Everyday Life, has increased its power of domination. The repertoire of stra-tactic applications is not as 
rich as tactics. However, it is possible to discuss two behavior typologies of stra-tactic. The first resembles self orientation: with the goal to defend itself, it redefines itself according to the dominant paradigm. The second is pretension. In both typologies, we observe intentions resembling 'approval' and 'defense' at the very foundation which actually lie in the motive of 'transcending time dependence'. However neither of these results in anything different than the consolidation of sovereignty and hegemony.

Diken (1998) states that when Freud, in order to respond to anti-Semitism, says that Moses is of Egyptian descent in his work Moses and Monotheisim, he is actually saying that "Jews don't exist." Similarly, "Žižek, in using Pascal's ideas, states that many ideologies gain acceptance and have an effect in society not only because people unconsciously believe in them, but because they pretend as if they actually do believe in them." (Diken, 1998, p. 71). At its very foundation, enchantment's significance lies in the awareness of the relationship of all the extensions of the discourse revolving around "Enchanting the Street." Here a moral arena appears because emotions, knowledge, actions and sensitivity, as a whole or individually, become the topic of discussion.

In this understanding, Mestrovic's (1999) concept of post-emotionalism carries important clues related to agency. Hodgson reads the transformation that the West went through, by means of a concept which comprises all of its different fronts, with technicalization. He even states that the concepts of 'rational' and 'traditional' carry technical meanings as the characteristics that separate modern from pre-modern (Hodgson, 2001). In this process of confusing knowledge with ideology, technical knowledge has taken the place of ideological/religional knowledge, technical application and its outcomes, as well the intellectual arena. This change of place results in their worlds of meaning to be reconstructed. According to A. Arslan (1997), transformation of the concept of morality and epistemological break between these concepts and their ontological context culminate in the secularization of Muslims. However, among different ideologies/beliefs, concepts cannot become isolated and change places from an ontological context, especially the concepts of 'knowledge's (revelation) active existence (sunnah)' which appear in Islam. This would be a completely meaningless change of place, which would be a wondrous job for stra-tactic implementations to achieve. As a result, 'enchanting the street' would require such an implementation that all changes were to be managed at the same time.

\section{Kaynakça / References}

Akşit, B., Şentürk, R., Küçükural, Ö. ve Cengiz, K. (2012). Türkiye'de dindarlık: Sosyal gerilimler ekseninde inanç ve yaşam biçimleri. İstanbul: Illetişim Yayınları.

Altun, F. (2005). Modernleşme kuramı: Eleştirel bir giriş. İstanbul: Küre Yayınları. 
Arslan, A. (1997). Seküler dünyada Müslümanlar. Birikim Dergisi, 99, 30-39.

Arslan, A. (2009). Sabra davet eden hakikat. İstanbul: Pınar Yayınları.

Arslan, M. (2010). Seküler toplumlarda kutsal arayışları: Geç modern dönemde büyü-din ilişkisinin sosyolojik analizi. i.Ü. Ilahiyat Fakültesi Dergisi, 1(1), 195-210.

Asad, T. (2007). Sekülerliğin biçimleri: Hristiyanlık, İslamiyet ve modernlik (çev. F. B. Aydar). İstanbul: Metis Yayınları.

Berger, P. L. ve Luckmann, T. (2008). Gerçekliğin sosyal inşası: Bir bilgi sosyolojisi incelemesi (çev. V. S. Öğütle). İstanbul: Paradigma Yayıncılık.

Bezci, B.ve Miş, N. (2012). İslamcılığın dönüşümünü tartışmak: İslamcılığın dört hali ve muhafazakarlaşmak. Bilgi Dergisi, 24, 1-17.

Cantek, L. (2008). Cumhuriyetin büluğ çağı: Gündelik yaşama dair tartışmalar (1945-1950). İstanbul: İletişim Yayınları.

Çınar, M. (1997). Yükselen değerlerin işadamı cephesi: MÜSiAD. Birikim Dergisi, 95, 52-57.

De Certeau, M. (2008). Gündelik hayatın keşfi I: Eylem, uygulama, üretim sanatları (çev. L. Arslan Özcan). Ankara: Dost Kitabevi.

De Certeau, M., Giard, L. ve Mayol, P. (2009). Gündelik hayatın keşfi ll: konut, mutfak işleri (çev. Çağrı Eroğlu ve Erkan Akçay). Ankara: Dost Kitabevi.

Diken, B. (1998). İdeolojik fanteziler: İçimizdeki faşizm. Birikim Dergisi, 107, 71-79.

Eroğlu, E. (2011). Tüketici hukuku ders notu. http://www.turkhukuksitesi.com/makale_1364.htm adresinden 12 Mayıs 2012 tarihinde edinilmiştir.

Foucault, F. (2006). Hapishanenin doğuşu: Gözetim altında tutmak ve cezalandırmak (çev. M. A. Kılıçbay). Ankara: İmge Kitabevi.

Frankl, G. (2003). Batı uygarlığı: Ütopya ve trajedi (çev. Y. Kaplan). İstanbul: Açılım Kitap.

Göle, N. (2009). Batı dışı modernlik: Kavram üzerine. (M. Gültekingil ve T. Bora (Ed.), Modern Türkiye'de siyasi düşünce içinde (C. 3, s. 56-67). İstanbul: İletişim Yayınları.

Göle, N. (2012). Seküler ve dinsel: Aşınan sınırlar (çev. E. Ünal). İstanbul: Metis Yayınları.

Guenon, R. (1990). Niceliğin egemenliği ve çağın alametleri (çev. M. Kanık). İstanbul: İz Yayıncılık.

Habermas, J. (1999). Meşruiyet dayanağı olarak insan hakları (çev. T. Bora ve M. Sancar). Birikim Dergisi, $118,62-69$.

Habermas, J. (2001). Iletişimsel eylem kuramı (çev. M. Tüzel). İstanbul: Kabalcı Yayınevi.

Hanefi, H. ve Cabiri, M. (2011). Doğu Batı tartışmaları (çev. M. Coşkun). İstanbul: Mana Yayınları.

Hodgson, M. G. (2001). Dünya tarihini yeniden düşünmek (çev. A. Kanlıdere ve A. Aydoğan). İstanbul: Yöneliş Yayınları.

Horkheimer, M. (2010). Akıl tutulması (çev. O. Koçak). İstanbul: Metis Yayınları.

Kolakowski, L. (1999). Modernliğin sonsuz duruşması (çev. S. Ayaz). İstanbul: Pınar Yayınları.

Lefebvre, H. (1998). Modern dünyada gündelik hayat (çev. I. Gürbüz). İstanbul: Metis Yayınları.

Lefebvre, H. ve Regulier, K. (2005). Gündelik hayat ve ritmleri (çev. E. Gen). Birikim Dergisi, 191, 79-85.

Manzoor, S, P. (2008). Tanrı́yı terk etmeden tarihe sahip çıkmak: İslam, Sekülarizm ve dünyevileşme sorunu (çev. Y. Aşıkoğlu). Milel ve Nihal Dergisi, 5(2), 129-145. 
Manzur, P. (1990). İslam ve Batı: Denemeler (çev. Y. Z. Cömert ve İhsan Duru). İstanbul: İnsan Yayınları. Mert, N. (1998). İslam ve demokrasi: Bir kurt masalı. İstanbul: İz Yayıncılık.

Mestrovic, S. G. (1999). Duyguötesi toplum (çev. A. Yılmaz). İstanbul: Ayrıntı Yayınları.

Northbourne, L. (2000). Illerlemeye farklı bir bakış (çev. D. Özer). İstanbul: İnsan Yayınları.

Ocak, A. G. (2010). Türkiye sosyal tarihinde İslam'ın macerası: Makaleler-incelemeler. İstanbul: Timaş Yayınları.

Özdalga, E. (2007). İslamcılığın Türkiye seyri: Sosyolojik bir perspektif (çev. G. Türkoğlu). İstanbul: İletişim Yayınları.

Ritzer, G. (1998). Toplumun mcdonaldlaştırılması: Çağdaş toplum yaşamının değişen karakteri üzerine bir inceleme (çev. Ş. S. Kaya). İstanbul: Ayrıntı Yayınları.

Ritzer, G. (2011). Büyüsü bozulmuş dünyayı büyülemek: Tüketim araçlarının devrimcileştirilmesi (çev. Ş. S. Kaya). İstanbul: Ayrıntı Yayınları.

Schmitt, C. (2005). Siyasi ilahiyat: Egemenlik kuramı üzerine dört bölüm (çev. E. Zeybekoğlu). Ankara: Dost Kitabevi.

Subaşı, N. (2002). Türk(iye) dindarlığı: yeni tipolojiler. İslamiyat Dergisi, 5(4), 17-41.

Subaşı, N. (2007). Konya'da modernleşme ve gündelik hayatın yeniden üretimi. Şehir Araştırmaları Dergisi, 1, 15-27.

Şahin, Ö. ve Balta, E. (2001). Gündelik yaşamı dönüştürmek ve marksist düşünce. Praksis Dergisi, 4, 185217.

Taylor, C. (2006). Modern toplumsal tahayyüller (çev. H. Koyukan). İstanbul: Metis Yayınları.

Tekin, M. (2003). Tanrı kavramı ve toplumsal izdüşümü. Selçuk Üniversitesi Sosyal Bilimler Enstitüsü Dergisi, 10, 475-492.

Tekin, M. (2011). Türkiye toplumunun dini hayatında postmodern tezahürler. I.Ü. Illahiyat Fakültesi Dergisi, 25, 5-28.

Virilio, P. (1998). Hız ve politika (çev. M. Cansever). İstanbul: Metis Yayınları.

Yılmaz, F. (2009). Rasyonalite: iktisat özelinde bir tartışma. İstanbul: Paradigma Yayıncılık. 